\title{
2. SITE 581: DOWNHOLE SEISMOMETER EXPERIMENT IN THE NORTHWEST PACIFIC ${ }^{1}$
}

\author{
Shipboard Scientific Parties, with contributions by Audrey W. Meyer and James H. Natland ${ }^{2}$
}

\section{HOLE 581A}

Date occupied: 25 August 1982

Date departed: 27 August 1982

Time on hole: 2 days, $5 \mathrm{hr}$.

Position (latitude, longitude): $43^{\circ} 55.46^{\prime} \mathrm{N}, 159^{\circ} 47.79 \mathrm{E}$

Water depth (sea level; corrected m, echo-sounding): 5467

Water depth (rig floor; corrected m, echo-sounding): 5483

Bottom felt (m, drill pipe): 5480

Penetration (m): 374.8

Number of cores: 4

Total length of cored section (m): 46.6

Total core recovered $(\mathrm{m}): 4.65$

Core recovery (\%): 9.9

Oldest sediment cored:

Depth sub-bottom (m): 359

Nature: Chert

Age: Unknown

Measured velocity $(\mathrm{km} / \mathrm{s}): 4.40$

Basement:

Depth sub-bottom (m): 360

Nature: Basalt

Velocity range $(\mathrm{km} / \mathrm{s}): 4.02-5.71$

\section{HOLE 581B}

Date occupied: 28 August 1982

Date departed: 5 September 1982

Time on hole: 8 days, $6 \mathrm{hr}$.

Position (latitude, longitude): $43^{\circ} 55.66^{\prime} \mathrm{N}, 159^{\circ} 47.77^{\prime} \mathrm{E}$

Water depth (sea level; corrected m, echo-sounding): 5467

Water depth (rig floor; corrected m, echo-sounding): 5483

Bottom felt (m, drill pipe):

Penetration (m): 375.0

Number of cores: 6

\footnotetext{
${ }^{1}$ Duennebier, F. K., Stephen, R., Gettrust, J. F., et al., Init. Repts. DSDP, 88: Washington (U.S. Govt. Printing Office).

2 Addresses: (Shipboard Scientific Parties) Frederick K. Duennebier (Co-Chief Scientist), Hawaii Institute of Geophysics, University of Hawaii at Manoa, 2525 Correa Rd., Honolulu, HI 96822; Ralph A. Stephen, (Co-Chief Scientist), Department of Geology and Geophysics, Woods Hole Oceanographic Institution, Woods Hole, MA 02543; Joseph Gettrust (Co-Chief Scientist), Naval Ocean Research and Development Activity, NORDA Code 253, NSTL Station, MS 39529; Felix Avedik, Centre Océanologique de Bretagne, B.P. 337, 29273 Brest Cedex, France: J. Alan Balland, Naval Ocean Research and Development Activity, NORDA Code 543, NSTL Station, MS 39529; L. Dale Bibee, School of Oceanography, Oregon Ste versity, Corvallis, OR 97331 (present address: Earth and Space Sciences Division, Los Alamos National Laboratory, Los Alamos, NM 87545); Anton Inderbitzen, Office of Scientific Ocean Drilling, National Science Foundation, 1800 G Street NW, Washington, D.C. 20550; Randall Jacobsen, School of Oceanography, Oregon State University, Corvallis, OR 97331; Georges Pascal, Université de Bretagne Occidentale, Avenue le Gorgeu, 29283 Brest Cedex, France: (Meyer) Ocean Drilling Program, 500 University Drive West, Texas A\&M University College Station, of Oceanography, La Jolla, CA 92093.
}

Total length of cored section (m): 24.5

Total core recovered $(\mathrm{m}): 13.12$

Core recovery (\%): 54

Oldest sediment cored:

Depth sub-bottom (m): 350

Nature: Chert

Age: Unknown

Measured velocity $(\mathrm{km} / \mathrm{s})$ :

Basement:

Depth sub-bottom (m): 351

Nature: Basalt

Velocity range $(\mathrm{km} / \mathrm{s}): 4.70-5.27$

\section{HOLE 581C}

Date occupied: 8 September 1982

Date departed: 13 September 1982

Time on hole: 5 days, $9 \mathrm{hr}$.

Position (latitude, longitude): $43^{\circ} 55.44^{\prime} \mathrm{N}, 159^{\circ} 47.84^{\prime} \mathrm{E}$

Water depth (sea level; corrected m, echo-sounding): 5467

Water depth (rig floor; corrected m, echo-sounding): 5483

Bottom felt (m, drill pipe):

Penetration (m): 380.2

Number of cores: 4

Total length of cored section $(\mathrm{m}): 20.6$

Total core recovered $(\mathrm{m}): 16.1$

Core recovery $(\%): 78.2$

Oldest sediment cored:

Depth sub-bottom (m): 356

Nature: Chert

Age: Unknown

Measured velocity $(\mathrm{km} / \mathrm{s})$ :

Basement:

Depth sub-bottom (m): 357

Nature: Basalt

Velocity range $(\mathrm{km} / \mathrm{s}): 4.74-6.25$

Principal results: Hole 581, the pilot hole at Site 581, was drilled during Leg 86. Three additional holes were drilled during Leg 88 , two reentry and one single bit. The two reentry holes ended in failures caused probably by bad pipe, lack of experience with the very long and heavy drill strings, and interference of ice-rafted cobbles with the reentry casing. Whereas sediment recovery was minimal, al three holes penetrated basement and $32 \mathrm{~m}$ of basalt were cored.

The Hawaii Institute of Geophysics (HIG) ocean sub-bottom seismometer (OSS) was emplaced in Hole 581C. This instrument was used to obtain very good seismic-refraction data while Glomar Challenger was on site with the U.S.N.S. De Steiguer shooting, and it subsequently recorded 64 days of continuous seismic data after the ships left the site. Readers are referred to the seismic data chapters for further results.

The basalts are of diverse petrography, including olivine-rich, $\mathrm{Cr}$-spinel bearing pillows, and probable ferrobasalt pillows and flows. They were veined primarily with $\mathrm{Fe}-\mathrm{Mn}$ oxyhydroxides and calcite, with lesser clays in multiple events of mineralization. Oxi- 
dative alteration halos are prominent near the veins. The basalts were later pervasively altered under non-oxidative conditions during which pyrite and probable saponite formed throughout much of the rock.

\section{OPERATIONS}

Site 581 was reoccupied by Glomar Challenger at $1820 \mathrm{~L}$ $(Z+10)$, on 24 August 1982, after a survey of the site beginning at about 1040L. The long-life beacon left by Leg 86 was not heard, and a $16-\mathrm{kHz}$ beacon was dropped on the second pass over the site at $1410 \mathrm{~L}$, based on reflection-profile data. Because weather was so poor, surveying was continued until $1820 \mathrm{hr}$. Water depth measured using a precision depth recorder was $5455 \mathrm{~m}$ uncorrected, $5467 \mathrm{~m}$ corrected (area 48 ), and $5483 \mathrm{~m}$ to the rig floor.

Hole $581 \mathrm{~A}\left(43^{\circ} 55.46^{\prime} \mathrm{N}, 159^{\circ} 47.79^{\prime} \mathrm{E}\right)$ is located approximately $960 \mathrm{ft}$. south of Leg 86 , Hole $581\left(43^{\circ}\right.$ $55.62^{\prime} \mathrm{N}, 159^{\circ} 47.76^{\prime} \mathrm{E}$ ), the pilot hole for this site. Table 1 is a summary of cores obtained from the holes. The reentry cone was keelhauled at 0530L, 25 August, and the 16 -in. casing string $(72.15 \mathrm{~m})$ was completed at $1030 \mathrm{~L}$. The hole was spudded at $0235 \mathrm{~L}, 26$ August with difficulty, washing to the casing depth at $5552 \mathrm{~m}$. Since the pilot hole drilled on Leg 86 was washed to over $90 \mathrm{~m}$ without difficulty, this was a surprise. The first (wash) core was recovered at $1345 \mathrm{~L}$ at $5817 \mathrm{~m}$ depth. This core contained partly lithified muds, drill breccia, and various colored chert cobbles. Core 581A-1 contained one chert cobble, and Core 581A-2 was completely empty. Considerable torque and stıcking was encountered because of chert bands. Core 581A-3 reached basement at about $5840 \mathrm{~m}$ and we recovered about $4.5 \mathrm{~m}$ of basalt. Core 581A-4 was left in the pipe when drilling with the 14-in. bit was completed on 27 August at $0845 \mathrm{~L}$. The hole was washed and filled with mud, and the drill pipe pulled to prepare for 11 -in. casing. At $2145 \mathrm{~L}$ we found that the drill pipe had broken $0.5 \mathrm{~m}$ above the bottomhole assembly (BHA) during the hole-cleaning operation. The pipe had never been in compression and the loss is unexplained. Since a landing tool latch sleeve is in the throat of the cone, we could not fish for the BHA with the equipment on board, thus Hole 581A was abandoned.

Glomar Challenger was moved $600 \mathrm{ft}$. north at about 2300L, 27 August, to the approximate location of Leg 86 , Hole 581. Water depth at this point was measured on the precision depth recorder (PDR) to be within $1 \mathrm{~m}$ of that at Leg 88 , Hole $581 \mathrm{~A}$, but $3 \mathrm{~m}$ shallower than the depth recorded by Leg 86 at Hole 581. Glomar Challenger then moved an additional $400 \mathrm{ft}$. north to avoid confusion on reentry with the cone at Leg 88, Hole 581A.

Leg 88 , Hole $581 \mathrm{~B}\left(43^{\circ} 55.66^{\prime} \mathrm{N}, 159^{\circ} 47.77^{\prime} \mathrm{E}\right)$ was spudded at $1615 \mathrm{~L}, 29$ August and washed with great difficulty to bury the $72.27 \mathrm{~m}$ of 16 -in. casing. Three wireline tries were needed to release from the cone. The wash core barrel (581-H-1) recovered during the release operation contained $3.63 \mathrm{~m}$ of coarse mudstone sand. The

Table 1. Coring summary, Site 581.

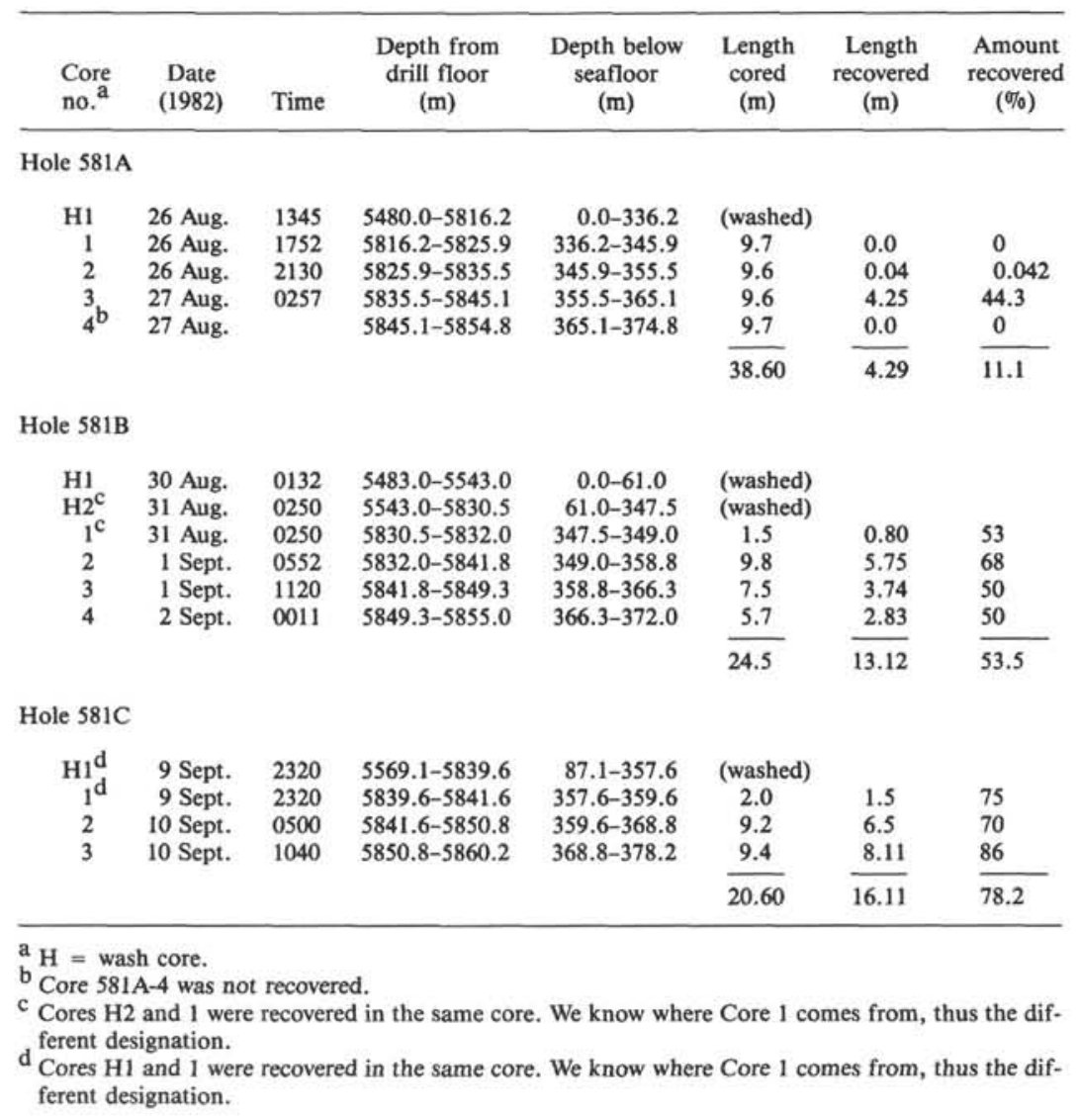


moderately well-rounded particles almost certainly were not generated by the washing-in operation. This material was probably responsible for the difficult washing, but see the section on igneous rocks for another interpretation. The cone was finally released at $0500 \mathrm{~L}, 30$ August, about $10 \mathrm{~m}$ above the mud line with indications of bent pipe. When the pipe was retrieved at $1600 \mathrm{~L}$, the mandrel of the bumper sub above the running tool was found to be bent. The pipe had gone into compression at one point during washing-in. The cone was reentered at $0836 \mathrm{~L}, 30$ August, with a 14-in. bit after $2 \mathrm{hr}$., 26 min. of scanning. The top of the cone was found to be approximately $17 \mathrm{~m}$ above the mud line, when it should have been only $3 \mathrm{~m}$ above it. It was apparently in good shape, however, and reentry with the 14-in. bit was accomplished easily.

Hole 581B was washed and drilled to $5830.5 \mathrm{~m}$, with torquing up to $8000 \mathrm{ft}$. lb. and considerable sticking in the chert beds. The pipe was stuck for $30 \mathrm{~min}$. just above the basalt. Basalt was cored between 5830.5 and $5835 \mathrm{~m}$ when the core barrel was recovered. Because of the nature of the material in this core barrel, the upper part (from the washing operation) containing chert cobbles and some manganese was designated Core $581 \mathrm{~A}-\mathrm{H}-2$ and the basalt part labeled Core 581A-1. The rationale is that we know what level the basalts come from, but not the cherts.

The De Steiguer arrived at the site at $2100 \mathrm{~L}, 31 \mathrm{Au}-$ gust, and $1500 \mathrm{lb}$. of batteries for the Marine Seismic System (MSS) were transferred immediately to Glomar Challenger in one of Glomar Challenger's life boats. De Steiguer had deployed one HIG ocean bottom seismometer (OBS) on approach to the site and would deploy four more HIG OBSs and five Oregon State University OBSs near the site during the next 2 days. The remainder of its time prior to shooting would be spent surveying near the site.

Coring in basalt with the 14-in. bit was completed at 1700L, 1 September, at a depth of $5855 \mathrm{~m}$ below the rig floor. The hole was filled with mud and the pipe was pulled from the hole. A trip with the EDO tool showed that the cone had not settled noticeably and was still about $17 \mathrm{~m}$ above the mud line. Pipe was then pulled and 39 joints of $113 / 4$-in. casing plus two slip joints picked up. This is the longest $113 / 4$-in. casing string ever run by Glomar Challenger.

At $1230 \mathrm{~L}, 1$ September, we were contacted by Dr. Yuri Neprochnov, Chief Scientist of the Soviet vessel Dimitri Mendeleev. They were planning to deploy ocean bottom seismometers to listen to the long refraction line to be shot by De Steiguer as part of the experiment. They requested information on when and where the explosives were to be set off and if it would be agreeable with us to emplace their OBSs $50 \mathrm{~km}$ to our west. They also asked if it would bother our experiment if they ran reflection profiles and a very large air-gun profile near Glomar Challenger. After consulting with De Steiguer, we agreed that there would be no problems with the Soviet plans, and very probably they would benefit the experiment. Although the air-gun profiles would be run prior to the MSS installation, they would be recorded by the OBS array. The requested information was passed to Dr. Ne- prochnov, and a message was sent to station WWD stating that we were in contact with a Soviet vessel.

Also during this period, an air drop was made to the De Steiguer of tape recorder parts needed by the MSS. Several tape heads had failed since leaving port, and replacements were flown to the site from Adak. The drop occurred in moderate fog about $200 \mathrm{~m}$ off the bow of De Steiguer and in sight of Glomar Challenger (although we could only see the plane on radar). Transfer of the parts in a steel drum and sonobuoy cases was done without problem by rope shot from Glomar Challenger to De Steiguer.

Reentry with the $113 / 4$-in. casing was first attempted at $1730 \mathrm{~L}, 3$ September. The EDO tool was bouncing continuously and had failed by $1830 \mathrm{~L}$. On retrieval the cable was found kinked just above the tool, and the tool needed work to repair electronics. The cable was reheaded and a second tool lowered. The second tool failed with similar characteristics to the first. The hole was finally reentered at $1234 \mathrm{~L}, 4$ September on the third EDO tool. The problem was apparently lack of pump pressure, which allowed the tool to bounce in the bottom of the pipe.

The 11-in. casing appeared to be set without problems and cementing was done. After attempting to unlatch the pipe from the casing, full weight of casing and pipe was taken, indicating that unlatching had not taken place. Rather than unlatching, the pipe was apparently spinning a slip joint in the casing. It was also noted that when weight was picked up and all slip joints compressed, pipe length indicated that the casing was not attached to the cone, but extending $9 \mathrm{~m}$ above it. With apparently no way to release the casing from the pipe, no way to get the casing deeper, or to pull it out, and Typhoon Gordon approaching, the pipe was blown off $5437 \mathrm{~m}$ below the rig floor at $0507 \mathrm{~L}, 5$ September, and Hole $581 \mathrm{~B}$ was lost.

With several hours to spare before having to heave to for Typhoon Gordon, an attempt was made to test the wireline re-entry tool. The test was unsuccessful because of a failure of the EDO tool.

Much of 6 September was spent surveying and waiting to see what Gordon would do. During this period of time, De Steiguer completed its surveying operation and headed $300 \mathrm{~km}$ south to begin shooting explosives. Without another reentry cone, with the EDO tools in poor shape, no $11^{3 / 4}$-in. casing, and time growing short we could not drill another hole for the MSS. Communications with shore and scientists on board suggested various options, including returning to Hakodate for another cone, building a cone from steel on board, and moving to Suiko Seamount where a cone already was in place. Most on board preferred to continue the leg as planned however, which meant emplacing the HIG ocean sub-bottom seismometer (OSS) in a single bit hole as quickly as possible to record the De Steiguer shooting, which would start on 9 September. Typhoon Gordon prevented any drilling activity, however, and Glomar Challenger could not drill for $56 \mathrm{hr}$. waiting on weather.

Hole $581 \mathrm{C}\left(43^{\circ} 55.44^{\prime} \mathrm{N}, 159^{\circ} 47.84^{\prime} \mathrm{E}\right)$ was finally spudded at 0830L, 9 September. De Steiguer had already started its shooting program to get data on the OBS ar- 
ray before it surfaced on 12 and 13 September. The hole was washed and drilled to basement with the familiar sticking and torque in the chert layers. Cores were labeled in a similar way to Hole $581 \mathrm{~B}$, with a wash core being split at the basalt into a wash core above and Core 1 below. This hole had excellent recovery in basalt with some unbroken sections more than $0.5 \mathrm{~m}$ long. Core $581 \mathrm{C}-3$ (the last core) bottomed $372.2 \mathrm{~m}$ below the mud line and $20.6 \mathrm{~m}$ into basalt. The mechanical bit release was then run and preparations made to run the OSS at 1300L, 10 September.

The OSS was successfully emplaced and recording of data aboard Glomar Challenger commenced. During the time that recording of OSS data was being carried out aboard Glomar Challenger, a total of 185 shots were fired by De Steiguer. A total of 27 hr. of continuous OSS data were recorded aboard Glomar Challenger prior to deployment of the seafloor recording package.

The anchor for the OSS was released, marking the end of the experiment at 2245L, 13 September. At this point, gale force winds and heavy seas prevented running pipe to start piston coring. Since the forecast suggested that there would be no break in the weather for $24 \mathrm{hr}$., it did not seem likely that there would be any time left for piston coring; thus the decision was made to leave the site and head for Yokohama.

\section{MSS DARPA EXPERIMENT}

During Leg 78B, the MSS borehole seismometer was emplaced, monitored, and retrieved from Hole 395A (Salisbury, Hyndman, et al., 1984). This test demonstrated that large, relatively fragile, instruments could be deployed downhole external to a drill string without entangling conductor cable and drill pipe or damaging the instrument on reentry. Downhole instruments were no longer restricted to $9.8-\mathrm{cm}$ diameter and 10 - to $12-\mathrm{m}$ length. A seismic shooting program conducted in conjunction with the deployment tests suggested that the quality of data was significantly improved relative to archived OBS data despite the fact that the seismometer was not clamped to the hole, it was tethered to the ship, and it was in a borehole with a considerable volume of water circulation. The results obtained on Leg 78B thus justified continuation and expansion of the program.

The long-term goals of the MSS station were (1) to obtain data from a wide range of earthquake magnitudes, first motions, and focal depths which will help to clarify processes associated with subduction (e.g., defining possible areas of tensional, compressional, and strikeslip faulting); (2) to determine the magnitude of changes of seismic properties of the oceanic crust with increasing age by establishing more precise epicentral locations and by recording signals from events whose propagation paths are undistorted by seamount or island roots; (3) to determine propagation characteristics of body and surface waves and evaluate source mechanisms within regional distances of an actively subducting plate boundary; and (4) to determine regional seismicity and the temporal variability of signal to noise. This information would be of value in discriminating between earthquakes and nuclear explosions.
In Holes 581A and 581B, two attempts were made to drill and case a borehole to basement. In both cases, the holes were readily drilled to basement but were lost because of apparent mechanical failures of the drilling equipment. Hole 581A was abandoned when the drill pipe broke $0.5 \mathrm{~m}$ above BHA during a wiping run just prior to retrieval for the second casing run. The cause of the pipe failure is not presently known, but parts of the drill pipe on board did not meet specifications and had caused trouble on previous legs.

On the second attempt (Hole 581B), the cone and 16in. casing could not be set to its complete depth. This caused no apparent problems when the hole was reentered to drill to basement or when it was reentered with the 11-in. casing string. The 11-in. casing string was set to the proper apparent depth and cemented, but could not be released from the drill string because of an apparent malfunction in the release mechanism. During efforts to release the casing, it became jammed in the hole, and could not be raised or lowered. The drill pipe was finally severed by an explosive charge and further efforts to prepare a borehole for the MSS seismometers were suspended because additional cones and casing were not available. Therefore, no program goals were accomplished during Leg 88. However, the MSS system was successfully deployed during Leg 91 (Site 595, Leg 91 portion of this volume).

\section{THE OCEAN SUB-BOTTOM SEISMOMETER EXPERIMENT}

The first permanent ocean borehole seismic system was emplaced on Leg 65 in Hole $482 \mathrm{C}$ (Lewis, Robinson, et al., 1983). The system, designed and built at the University of Hawaii, Hawaii Institute of Geophysics, was also successfully emplaced on Leg 67 in Hole 494A (Aubouin, von Huene, et al., 1982). An unsuccessful attempt was made to emplace the system on Leg 78A.

The purpose of the OSS experiment is to emplace a permanent borehole seismic system in the ocean crust and obtain earthquake data and information on the earth's interior. Data of this type are routinely obtained by ocean bottom seismometers (OBS) and hydrophones, but the quality of data is often poor and the instruments are usually only in place for short periods of time. A borehole system should couple well to the earth, unlike most OBSs which normally sit on soft sediments, and it should be far removed from noise caused by deep-ocean currents and shipping. The emplacement of both the MSS and the OSS in the same area with an OBS array could provide a unique data set for crustal structure, anisotropy, and earthquake studies.

A very basic question also needs to be answered: is the improvement in data quality and signal-to-noise ratio worth the added cost and complexity of emplacing seismic instruments in deep ocean boreholes? Although there have been four attempts at emplacement of borehole seismometers in the ocean crust (with the ship not connected to the hole by pipe), none of the attempts answered this question. The OSS experiment conducted on Leg 88 and comparison with the OBS array deployed by 
the De Steiguer have shown the value of ocean borehole seismometers.

\section{Experiment Design}

The controlling factor, and the main difference between the OSS and the MSS, is that the OSS is designed to be emplaced through the drill pipe while the MSS is too large and must be emplaced outside the drill pipe. The reader is referred to the chapter on the OSS experiment for a detailed description of the instrument and operations.

The OSS was emplaced in Hole 581C with a minimum of operational problems and no problems with the instrument itself. Stripping 195 stands of pipe and the BHA required about $12 \mathrm{hr}$. When the logging cable was reconnected and the tool clamped in the hole, data were recorded at 100 samples/s by the HIG system and passed in an analog format to the Defense Advanced Research Projects Agency (DARPA) MSS recording system, the Gould MSS recording system, and to the Oblique Seismic Experiment recorder. During this time, De Steiguer shot 185 explosive charges to the instrument in 10-km long lines at $45^{\circ}$ angles from the hole and one line to a range of $120 \mathrm{~km}$. Data quality from the OSS are very good on all three seismic axes. Low noise level and large shots resulted in excellent records for use in refraction and anisotropy studies.

The OSS recorder package, set to record continuous data from 12 September until 16 November 1982, was lifted over the side at $1500 \mathrm{~L}$ on 13 September 1982 . The rope and anchor assembly were released at $2245 \mathrm{~L}$ on 13 September.

The University of Hawaii's Kana Keoki reoccupied Site 581 on 25 May 1983. The acoustic transponders released properly and the recorder package was secure on deck at $0200 \mathrm{~L}, 26$ May. The 26 May magnitude 7.8 earthquake, at a range of about $15^{\circ}$, was felt and recorded on the ship about $8 \mathrm{hr}$. after the wire was picked up. Recovered data are excellent with about 1 earthquake/hr. for the whole 64-day period. The instrument is in excellent condition and a second package was emplaced to record data until mid-July, 1983.

\section{WIRELINE REENTRY TEST}

Wireline reentry is a method of reentering drill holes (or reoccupying any precise location) on the ocean floor without the drill string, but with only a bare wire and an instrument on the end. This procedure could be very important in the future since a drill ship is not required at the site. It will also allow large diameter (up to 8 in.) instruments to be emplaced, and possibly side wall coring of poorly sampled holes. V. F. Larsen and Don Bellows at the Deep Sea Drilling Project developed the tool and procedures to be used in this test. Figure 1 shows the different parts of the wireline reentry system. The reentry procedure is as follows: the tool is lowered close to the bottom, moved to a location near the cone using the ship's positioning beacon; then the EDO tool is used to locate and enter the cone.

The assembly of the wireline reentry tool commenced at $1445 \mathrm{hr}$. on 5 September. The Schlumberger line was

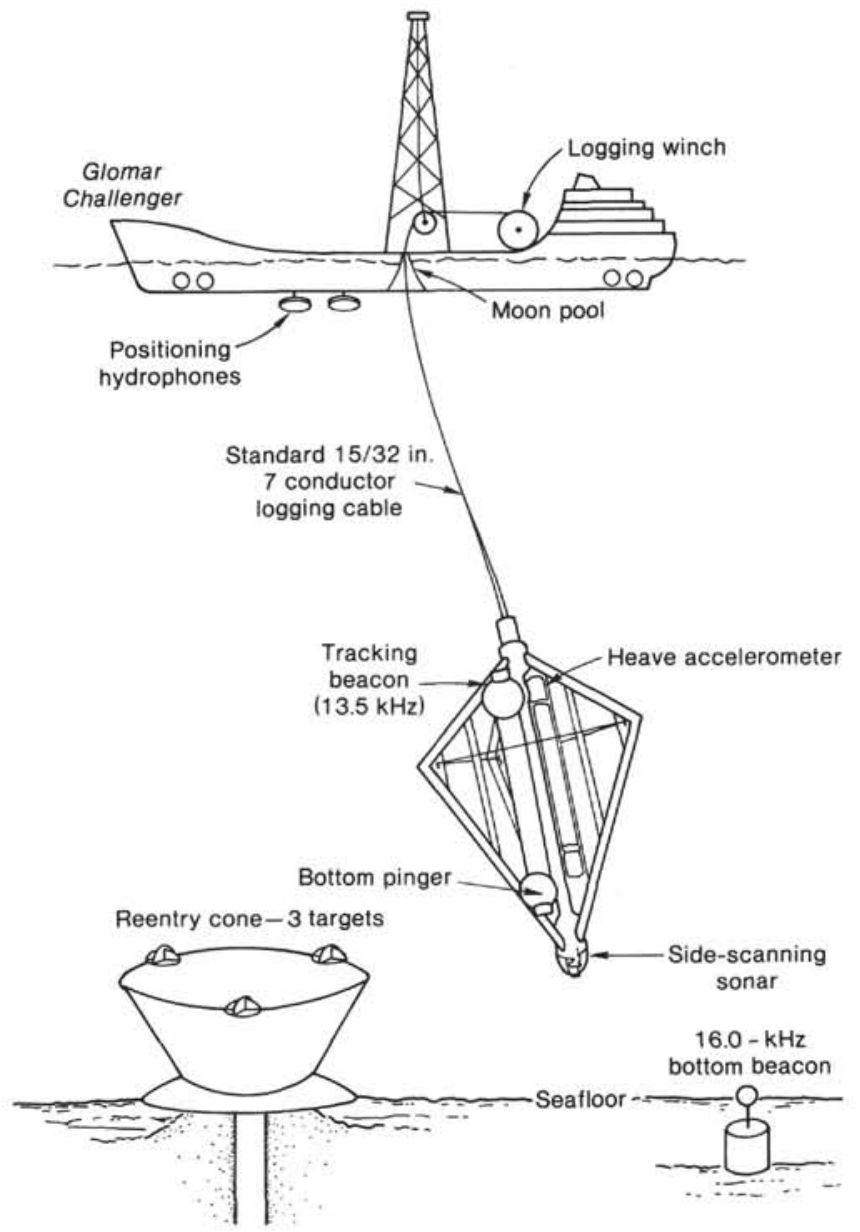

Figure 1 . The wireline reentry system.

keelhauled and tests of the reentry unit on deck were made at $1845 \mathrm{hr}$. The tool was lowered to $3000 \mathrm{~m}$ and its tracking capability with the ship's dynamic positioning computer was checked. The reference beacon on the seafloor was $16 \mathrm{kHz}$ and a $13.5-\mathrm{kHz}$ beacon was attached to the tool. The beacons were located relative to the ship alternately. The tests were carried out between 2005 and $2230 \mathrm{hr}$. Gear was on board by $0100 \mathrm{hr}$. on 6 September. Total time for the tests was $10 \mathrm{hr}$. and $45 \mathrm{~min}$. Because of tool malfunction, our objectives were reduced to determining how well the tool could be tracked under the ship and testing the feasibility of locating the tool with the present shipboard computer facilities.

The most basic position data were the raw $X, Y$ positions of the two transponders relative to the ship, available approximately every $6 \mathrm{~s}$, from either the 13.5 - or $16.0-\mathrm{kHz}$ transponders. These values were recorded for 1 to $5 \mathrm{~min}$. and averages were taken to reduce scatter caused by ship motion. We made two testing experiments. First, in order to check the effect of currents on the tool the ship was held as close as possible over the cone while lowering the tool to $3000 \mathrm{~m}$. The second experiment was to move the ship a known distance and to see how the tool and cable would follow this movement. This second phase could not be carried out because of unexpected instrumental difficulties encountered. 
The first conclusions of these experiments show the following:

1. At least to a depth of $3000 \mathrm{~m}$ the tool remains within $300 \mathrm{ft}$. of the ship, that is almost directly below it. Therefore, the effect of any current in this area seems to be negligible at this resolution.

2. Tool motions generally lag ship's motions with a 10 - to $15-\mathrm{min}$. delay time. This magnitude of delay is less than a factor of two longer than that of the pipe itself. Observed tool motions are generally slower than ship's motions.

3. Although it is possible to keep the tool within a $300 \mathrm{ft}$. radius by maneuvering the ship, controlling the tool to within $10 \mathrm{ft}$. of a fixed point was not possible because of the poor knowledge of ship and tool locations and motions and the difficulty in holding the ship stationary, even with dynamic positioning.

\section{SEDIMENTS CORED AT SITE 581 DURING LEGS 86 AND 88}

A pilot hole, Hole 581, was drilled to basement during Leg 86 to allow Leg 88 to plan their casing program for the DARPA downhole seismometer experiment. This hole was rotary cored from 181.5 to $353.5 \mathrm{~m}$ sub-bottom. The lithologies encountered are divided into four units. Unit I (181.5-244.8 m sub-bottom) is a biosiliceous clay that is divided into two subunits on the basis of color and the abundance of biosiliceous material. Subunit IA (191.5-223.6 m sub-bottom) is a reduced greenish gray biosiliceous clay of late Miocene to earliest Pliocene age characterized by abundant diatoms and radiolarians (up to $65 \%$ ). Subunit IB (223.6-244.8 m sub-bottom) is an oxidized yellowish-brown biosiliceous clay of latest middle Miocene to late Miocene age containing up to $25 \%$ biosiliceous material. Unit II (244.8$276.6 \mathrm{~m}$ sub-bottom) consists of brown to dark brown pelagic clay of presumed middle Miocene age and older. Unit III (276.6-343.0 m sub-bottom) consists of nothing but off-white, red, yellow, and dark brown chert fragments. Recovery of the Unit III cored interval was poor, and drilling rates suggest that most of the unrecovered section is soft sediment. Unit IV (343.0-352.5 m subbottom) recovered medium gray aphyric basalt. These basalts are described in the next section. Sediments were obtained in one wash core (designated $\mathrm{H} 1$ ), and just above basement (Core 2) at Hole 581A, in two wash cores (H1 and $\mathrm{H} 2$ ) at Hole 581B, and in one wash core ( $\mathrm{H} 1)$ at Hole 581C during Leg 88 . The sediments are like those of Hole 581 but their interval is uncertain (except for Core 581A-2) and ages unknown, since microfossils were not examined. Core 581A-2 consists of chert pebbles.

\section{IGNEOUS ROCKS CORED AT SITE 581 DURING LEGS 86 AND 88}

A rounded cobble of andesite, $5 \mathrm{~cm}$ in diameter, was recovered below disturbed pelagic clay in wash core $\mathrm{H} 1$ of Hole 581C. The rock is strongly porphyritic, with abundant phenocrysts and glomerocrysts of plagioclase and pyroxene, plus lesser opaque minerals. The sample was obtained in a core barrel retrieved after the reentry casing had become stuck some $17 \mathrm{~m}$ short of the wash- in objective for placing the reentry cone. The pebble obviously represents an ice-rafted erratic encountered near the top of the sediments (in Pleistocene hemipelagic oozes) that was carried downward ahead of the casing and bit until pelagic clay was reached (276.6-343.0 m sub-bottom), when it was finally cored. Since circulation during wash-in was designed to carry washed sediments between the drill collars and the casing (rather than outside the casing), cobbles such as this could not be pushed aside or flushed out of the hole. In all likelihood, the accumulation of such cobbles (and perhaps cherty fragments) led to the sticking of the casing short of its objective.

Basalts were cored in all four holes drilled at Site 581, with the maximum penetration into basement at Hole $581 \mathrm{C}(20.6 \mathrm{~m})$. Descriptions and chemical analyses are reported in Fountain et al. (1985). Recovery was good, ranging from about 40 to $85 \%$ per core, and averaging $59 \%$ during Leg 88 . The lavas range from small pillows, $20-50 \mathrm{~cm}$ in diameter, to substantial flows over $5 \mathrm{~m}$ thick. Compositionally, the rocks are abyssal tholeiites, some of them being highly magnesian and olivine rich (greater than $15 \% \mathrm{MgO}$, less than $0.8 \% \mathrm{TiO}_{2}$ ), others aphyric ferrobasalt (greater than $12 \%$ iron as $\mathrm{Fe}_{2} \mathrm{O}_{3}, 1.8-2.2 \%$ $\mathrm{TiO}_{2}$ ). This range is consistent with variations expected at a rapidly spreading ridge.

Alteration has significantly modified certain minor oxide and trace element abundances, notably causing enrichments in $\mathrm{K}_{2} \mathrm{O}, \mathrm{Rb}, \mathrm{Ba}$, and other mobile elements. The rocks are pervasively altered. All glass has been transformed to clay minerals. Veins are filled with brick-red iron oxyhydroxides, dark green or black clays, and carbonate minerals. Prominent red oxidation halos parallel fractures filled with iron oxyhydroxides. Some vein mineral erosion and redeposition took place at the time when fluids were evidently rapidly and vigorously flowing through the rocks. These left size-graded and sorted minibeds of former vein mineral particles in widened, inclined fractures in the basalts. These are now cemented by carbonate. In thin sections, a second episode of alteration is evident, represented by abundant pyrite and associated pale yellow clays (probably saponite) distributed widely in the groundmass of the rocks.

\section{PHYSICAL PROPERTIES}

Both basalt samples and three chert cobbles at the base of the wash core from Hole 581A were measured for sound velocity and density. Sound velocity and density measurements were made by the Hamilton Frame and the GRAPE apparatus, respectively.

Table 2 summarizes all the sound velocity and 2-min GRAPE density determinations at the three sites. Figure 2 shows the vertical distribution of the sound velocity with depth. Sub-bottom depth for each sample was computed by assuming: (1) the top of the core is where the core began, (2) any void is at the bottom of the interval, and (3) each previous core section is exactly $150 \mathrm{~cm}$ long. The distance down in a section is the centimeter position of the center of the piece used, including gaps and spaces in the core section. Exact depth of origin for the three chert cobbles in Hole 581A could not be determined as they were at the base of the wash core. The wash core 
Table 2. Sound velocity and density values at Holes 581A, 581B, and $581 \mathrm{C} .^{\mathrm{a}}$

\begin{tabular}{|c|c|c|c|c|}
\hline $\begin{array}{c}\text { Core-Section } \\
\text { (interval in cm) }\end{array}$ & $\begin{array}{l}\text { Piece } \\
\text { number }\end{array}$ & $\begin{array}{l}\text { Sub-bottom } \\
\text { depth } \\
\text { (m) }\end{array}$ & $\begin{array}{l}\text { Velocity } \\
(\mathrm{km} / \mathrm{s})\end{array}$ & $\begin{array}{l}\text { Wet-bulk } \\
\text { density } \\
\left(\mathrm{g} / \mathrm{cm}^{3}\right)\end{array}$ \\
\hline \multicolumn{5}{|l|}{ Hole 581A } \\
\hline $\mathrm{H}-1,48$ & Green chert & $<336.20$ & 4.02 & 2.22 \\
\hline $\mathrm{H}-1,52$ & Red chert & $<336.2$ & 4.11 & 2.07 \\
\hline $\mathrm{H}-1,56$ & Black chert & $<336.2$ & 5.08 & 2.64 \\
\hline $3-1,44-46$ & 3 & 355.95 & 5.24 & 2.88 \\
\hline $3-1,146-149$ & $5 \mathrm{H}$ & 356.98 & 5.66 & 2.95 \\
\hline $3-2,98-120$ & 6 & 358.00 & 5.65 & 3.05 \\
\hline $3-3,128-130$ & 6 & 359.79 & 5.71 & 3.03 \\
\hline $3-4,29-31$ & 3 & 360.30 & 5.30 & 3.03 \\
\hline \multicolumn{5}{|l|}{ Hole 581B } \\
\hline $1-1,27-29$ & 3 & 347.78 & 5.05 & 2.86 \\
\hline $2-1,113-116$ & $9 \mathrm{~B}$ & 350.15 & 5.07 & 2.83 \\
\hline $2-2,124-128$ & $12 \mathrm{~B}$ & 351.76 & 4.97 & 2.94 \\
\hline $2-3,83-87$ & 8 & 352.85 & 5.16 & 2.84 \\
\hline $2-4,45-49$ & $4 \mathrm{~A}$ & 353.97 & 5.17 & 2.87 \\
\hline $2-5,47-49$ & 4 & 355.47 & 4.61 & 2.77 \\
\hline $3-1,91-92$ & 10 & 357.71 & 4.70 & 2.95 \\
\hline $3-2,90-92$ & $7 \mathrm{~B}$ & 361.21 & 5.14 & 2.99 \\
\hline $3-3,60-61$ & 6 & 362.40 & 4.96 & 2.92 \\
\hline $4-1,68-70$ & $7 \mathrm{C}$ & 366.99 & 4.81 & 2.85 \\
\hline $4-1,139-141$ & $7 \mathrm{M}$ & 367.70 & 5.27 & 2.91 \\
\hline $4-2,33-35$ & 3 & 368.14 & 5.11 & 2.95 \\
\hline $4-2,110-112$ & 7 & 368.91 & 5.16 & 2.89 \\
\hline \multicolumn{5}{|l|}{ Hole 581C } \\
\hline $1-1,69-71$ & $8 \mathrm{~A}$ & 358.30 & 5.18 & 2.84 \\
\hline $1-1,109-111$ & $8 \mathrm{D}$ & 358.70 & 5.76 & 3.03 \\
\hline $2-1,38-40$ & $3 \mathrm{C}$ & 359.99 & 5.10 & 2.90 \\
\hline $2-2,25-27$ & 4 & 361.36 & 4.83 & 2.86 \\
\hline $2-3,29-32$ & $3 \mathrm{~A}$ & 362.91 & 5.12 & 2.84 \\
\hline $2-4,8-10$ & $1 \mathrm{~A}$ & 364.19 & 5.36 & 2.88 \\
\hline $2-5,22-25$ & $1 \mathrm{~A}$ & 365.84 & 6.11 & 3.07 \\
\hline $3-1,8-10$ & IA & 368.89 & 5.85 & 3.02 \\
\hline $3-2,20-22$ & $1 \mathrm{~A}$ & 370.51 & 6.25 & 3.10 \\
\hline $3-3,18-20$ & 1A & 371.99 & 6.19 & 3.11 \\
\hline $3-4,7-8$ & $1 \mathrm{~A}$ & 373.38 & 6.19 & 3.12 \\
\hline $3-5,12-14$ & $2 \mathrm{~A}$ & 374.93 & 4.74 & 2.81 \\
\hline $3-6,138-140$ & 9G & 377.69 & 4.92 & 2.88 \\
\hline
\end{tabular}

${ }^{a}$ Samples are basalts unless indicated otherwise.

represented the entire sediment section from the mud line to a sub-bottom depth of $336.2 \mathrm{~m}$, yet it contained very little material other than these three cobbles.

\section{Sound Velocity}

The sound velocity values within the basalt range from 4.61 to $6.25 \mathrm{~km} / \mathrm{s}$. The average minimum value for the three sites is $4.86 \mathrm{~km} / \mathrm{s}$ and the average maximum value is $5.74 \mathrm{~km} / \mathrm{s}$. Sound velocity appears to increase with depth into the basalt in Holes 581A and 581C except for the deepest values. In Hole $581 \mathrm{~A}$, there is a decrease in sound velocity from 5.71 to $5.30 \mathrm{~km} / \mathrm{s}$ from a sub-bottom depth of 359.8 to $360.3 \mathrm{~m}$. A more significant decrease is noted near the bottom of Hole 581C, where the sound velocity decreases from $6.19 \mathrm{~km} / \mathrm{s}$ at $373.4 \mathrm{~m}$ to $4.74 \mathrm{~km} / \mathrm{s}$ at $374.9 \mathrm{~m}$.

The velocity values at Hole 581B are more erratic, but generally increase with depth into the basalt. There are several places or zones within the cores where the velocity values decrease and then begin to increase again with increasing depth within the hole. The most significant of these decreases occurs between the sub-bottom depths of 354.0 and $355.5 \mathrm{~m}$, where the sound velocity decreases from 5.17 to $4.61 \mathrm{~km} / \mathrm{s}$.

\section{Wet-Bulk Density}

The density values within the basalt range from 2.77 to $3.12 \mathrm{~g} / \mathrm{cm}^{3}$. The average minimum value from the three sites is $2.82 \mathrm{~g} / \mathrm{cm}^{3}$ and the average maximum value is $3.05 \mathrm{~g} / \mathrm{cm}^{3}$. A similar change in both the density and physical appearance of the basalt from Hole $581 \mathrm{C}$ is quoted from 373.4 to $374.9 \mathrm{~m}$ sub-bottom. Density decreases from 3.12 to $2.81 \mathrm{~g} / \mathrm{cm}^{3}$. The basalt below $374 \mathrm{~m}$ is highly fractured and appears less competent than dense basalt within the $10+\mathrm{m}$ zone above this depth. The rapid decrease in sound velocity and density coupled with the change in the physical characteristics of the basalts below $374 \mathrm{~m}$ are believed to indicate a boundary between two flows at about this depth.

In Hole 581B, the decrease in velocity between the depths of 354.0 and $355.5 \mathrm{~m}$ is accompanied by a slight decrease in density and may represent a flow boundary. Yet the physical appearance of the basalt does not change appreciably throughout these depths.

\section{UNDERWAY GEOPHYSICS}

U.S.N.S. De Steiguer conducted a site survey concurrent with Glomar Challenger drilling at Site 581. The geophysical data collected by De Steiguer consist of 3.5-kHz high-resolution seismic profiles, sparker source single-channel hydrostreamer seismic reflection, and magnetometer data. During the site survey, De Steiguer deployed 10 ocean bottom seismograph (OBS) systems; seismic-refraction data for the OBSs provide constraints on the crust and upper-mantle structure in the region of the borehole seismic station.

To complement the site survey being conducted by $D e$ Steiguer, Glomar Challenger collected approximately 220 $\mathrm{km}$ of high-resolution seismic-reflection profiles prior to occupying Hole $581 \mathrm{~A}(3.5-\mathrm{kHz}$ hull-mounted transducer and towed air-gun sound sources). An additional $80 \mathrm{~km}$ of reflection records were available from Leg 86 . Bathymetry (12-kHz) records were also collected.

Additional geophysical data were collected by the Soviet research vessel Dimitri Mendeleev; these data include $222 \mathrm{~km}$ of single channel air-gun reflection lines, $259 \mathrm{~km}$ of multichannel lines, and $240 \mathrm{~km}$ of traverses with a very large air gun while Glomar Challenger was on site.

\section{Seismic-Reflection Surveys}

The seismic-reflection data set consists of $3.5-\mathrm{kHz}$, sparker air-gun data. The $3.5-\mathrm{kHz}$ records show three distinct types of reflections. Each reflecting zone is about $40 \mathrm{~m}$ thick (assuming $1500 \mathrm{~m} / \mathrm{s}$ sound speed). About 10 $\mathrm{km}$ north and west of Hole 581A, bottom reflectors are conformable, approximately equally spaced, and appear to be muted images of basement topography. Wavelengths of individual hills are about $3 \mathrm{~km}$, local relief is 10 to $20 \mathrm{~m}$, and the regional slope is toward the southwest at less than $1^{\circ}\left(\mathrm{A}-\mathrm{A}^{\prime}\right.$, Fig. 3). The Hole 581A beacon was dropped in an acoustically transparent zone (B-B' ${ }^{\prime}$, Fig. 3). The apparent thickness of the transparent zone is 10 

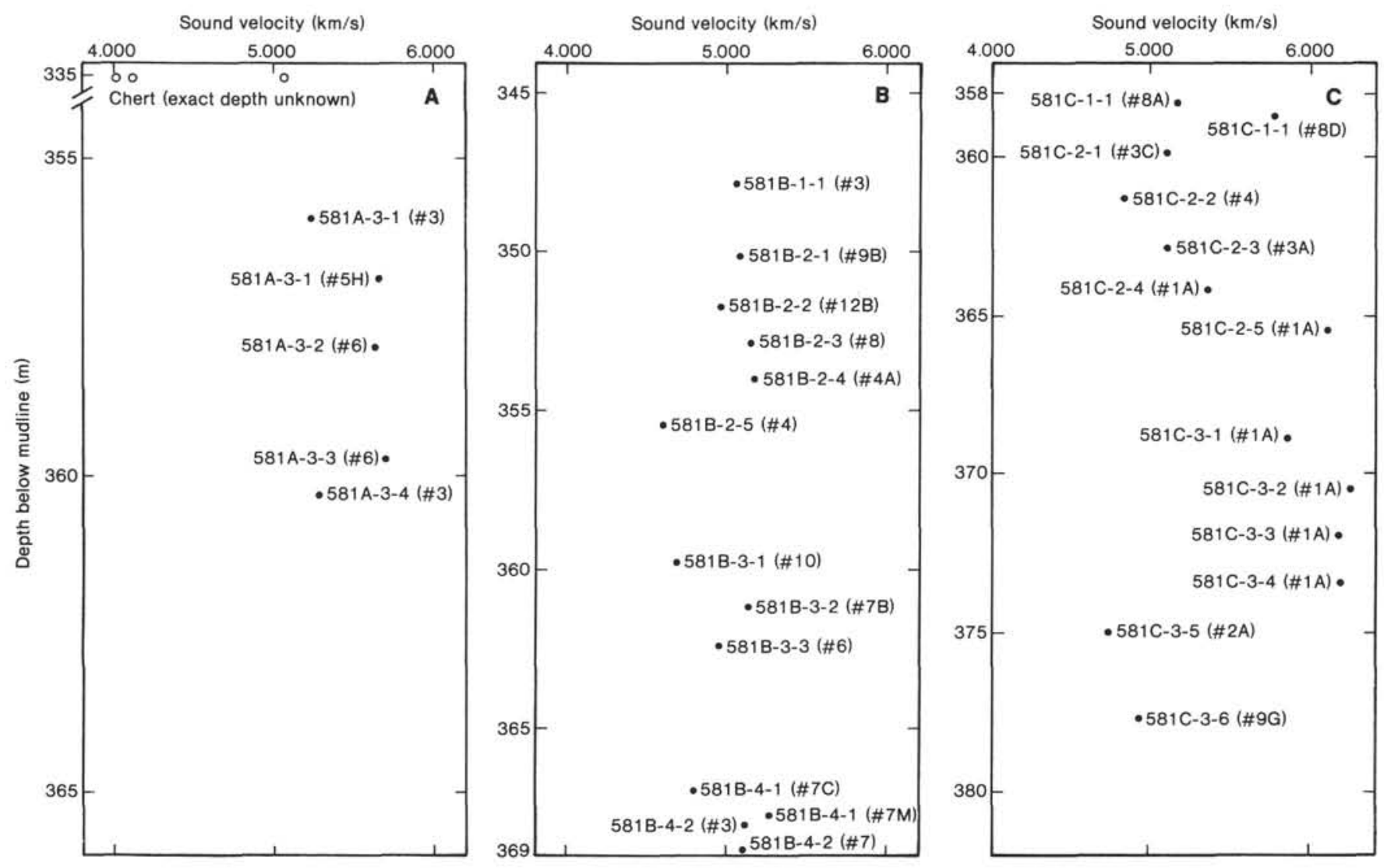

Figure 2. Sound velocity versus sub-bottom depth for (A) Hole 581A, (B) Hole 581B, and (C) Hole 581C. Pieces numbers are in parentheses next to sample label.

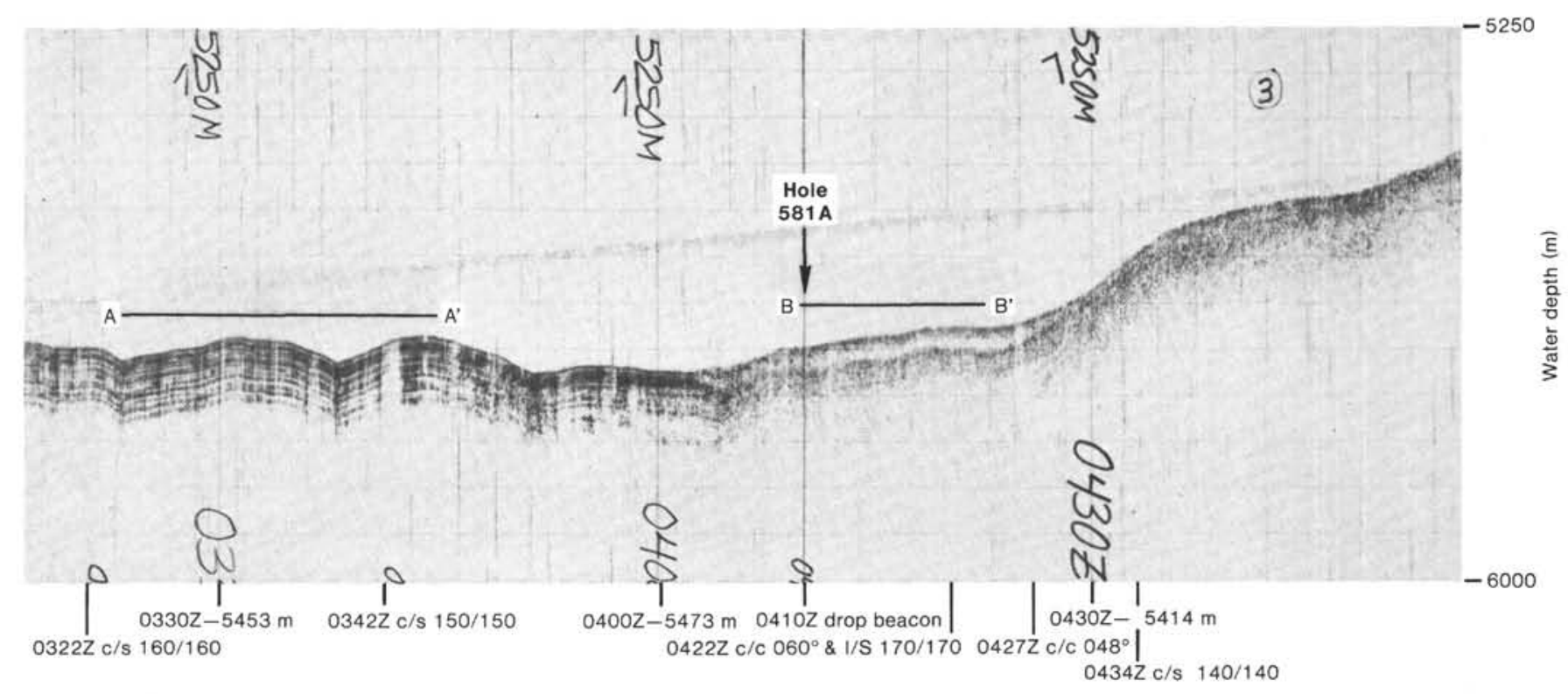

Figure 3. Glomar Challenger $3.5-\mathrm{kHz}$ record approaching Hole $581 \mathrm{~A}$.

to $15 \mathrm{~m}$. It is underlain by about 20 to $25 \mathrm{~m}$ of reverberant material that is devoid of coherent reflections. The transparent zone lies between the 5450 to $5460 \mathrm{~m}$ contours near the base of a $150-\mathrm{m}$ relief abyssal hill about $5 \mathrm{~km}$ northeast of Hole 581A. Heath, Burckle, et al.
(1985) suggest that the transparent zone may represent a debris flow. During attempts to set a cone for Hole 581B, $300 \mathrm{~m}$ north of Hole 581A, the core barrel returned a washed section of well-rounded, sand-sized mudstone fragments that appeared to be debris flow. The source 
of this material is not known, but it was returned in a wash core from a depth of less than $60 \mathrm{~m}$ below the mud line. The abyssal hill northeast of the drill site has an abrupt $50 \mathrm{~m}$ scarp along its western face (C, Fig. 4), which could be the source area.

On lines run south and southwest of the drill sites, the $3.5-\mathrm{kHz}$ section is about 40 to $50 \mathrm{~m}$ thick and does not contain laterally coherent reflectors (D-D', Fig. 5). Because the upper sedimentary column was not cored at this site, the $3.5-\mathrm{kHz}$ reflectors cannot be correlated with lithology.

The air-gun reflection profiles show four identifiable and traceable reflection horizons. These reflectors consist of a coherent group ranging from the mud line to a depth of about $100 \mathrm{~m}$, a transparent zone which contains a midsection reflector traceable throughout the area, a thin zone of coherent reflectors immediately overlying acoustic basement, and an acoustic basement typical of Layer 2. Below acoustic basement, coherent reflectors are not visible.
The uppermost coherent reflectors occur as a zone often conformable to underlying basement topography. The first 100-m section is, in part, an artifact of the data collection process (this is the width of the air-gun pulse) and does not represent a true geological environment. Nevertheless, it is useful to consider it as a reflecting entity that may be separated from underlying reflection patterns having more geological significance. The upper zone is $100 \mathrm{~m}$ thick, assuming an average vertical velocity of $1720 \mathrm{~m} / \mathrm{s}$. An average velocity of $1720 \mathrm{~m} / \mathrm{s}$ is consistent with the drilled depth to basement of $344 \mathrm{~m}$ measured at all four Site 581 drill holes and the $0.2 \mathrm{~s}$ one-way traveltime to acoustic basement at the beacon locations. This reflective pattern effectively screens structures occurring in the upper $100 \mathrm{~m}$, such as the transparent zone shown on the $3.5-\mathrm{kHz}$ echo sounder crossing of the drill site.

Seismic reflection data taken with the sparker source suggests two distinct "geoacoustic" provinces can be defined in the region near Site 581. To the west and

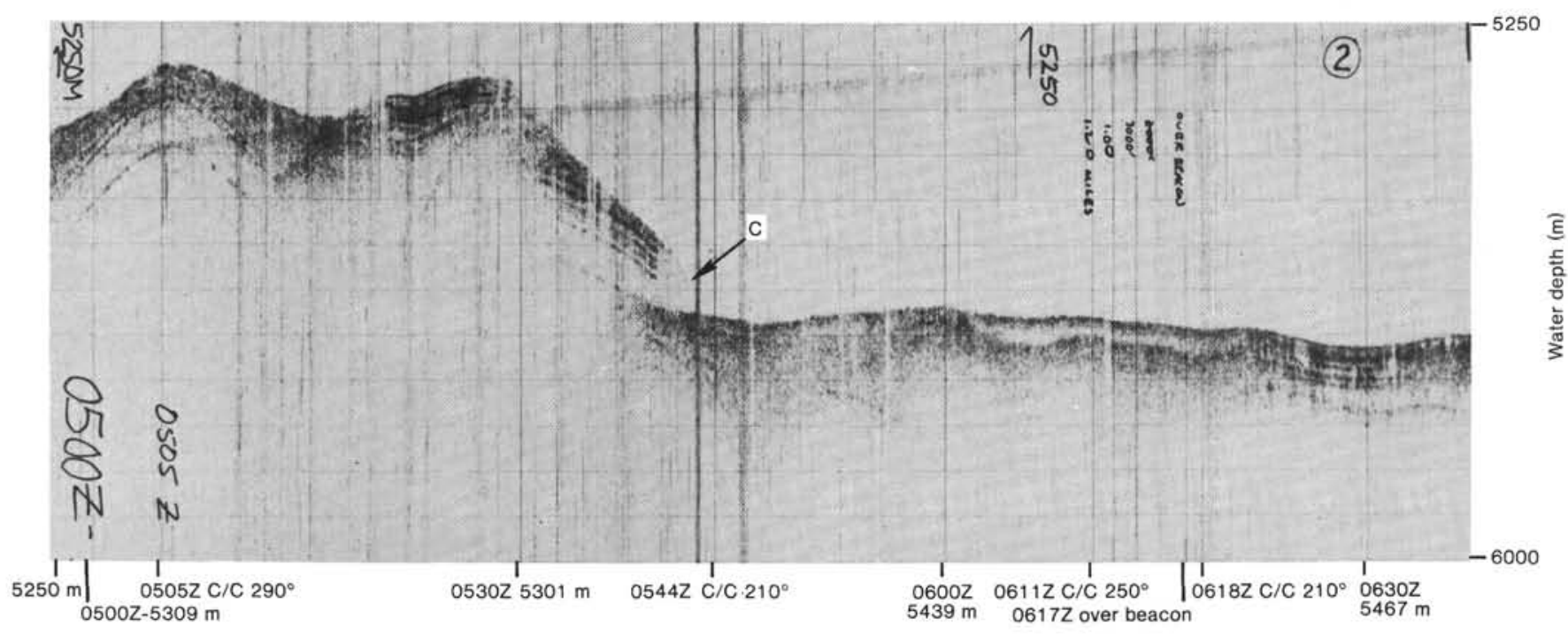

Figure 4. Glomar Challenger 3.5-kHz record NE of Hole 581B showing scarp near C.

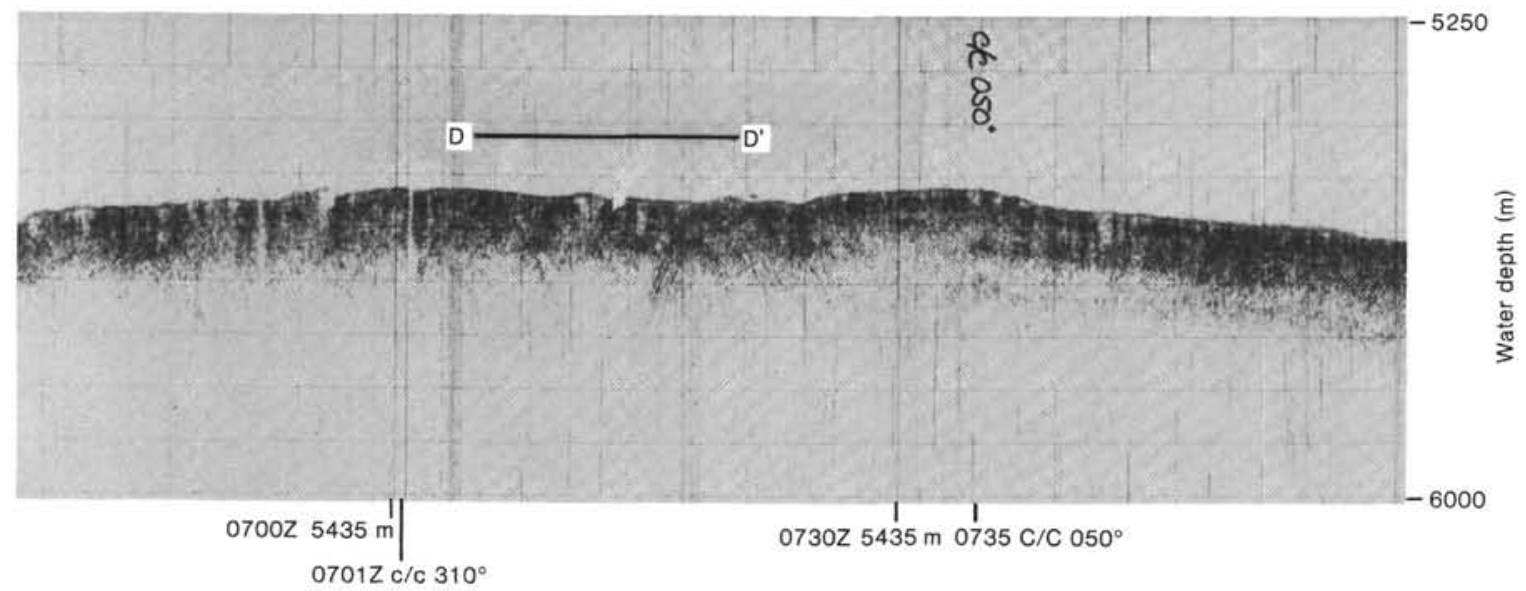

Figure 5. Glomar Challenger 3.5-kHz record S and SE of Holes at Site 581. D-D' does not have coherent reflectors. 
north of Site 581, the sediments are more acoustically transparent and are generally conformable with acoustic basement although the sediments thin at, and are occasionally pierced by, basement highs. To the northeast and south of Site 581, the sediment column is generally opaque; the seismic-reflection data suggest that Site 581 lies within the transition zone separating the more transparent sedimentation to the west and north with the more opaque section to the east and south.

A highly reflective horizon within the sediment column to the west of Site 581 can be identified in the profiles (E, Fig. 6). This reflector occurs at about 230 to $240 \mathrm{~m}$ sub-bottom and may correspond to lithologic Unit II. As defined by the Leg 86 preliminary report, lithologic Unit II is a brown, nonbiogenic, pelagic clay in which compressional-wave measurements show a small decrease in velocity.

A highly reflective layer lies between sub-bottom depths of about $290 \mathrm{~m}$ and acoustic basement (F, Fig. 6). In many cases, this group appears to merge with the more reverberant Layer 2 . In both depth and thickness these reflections correspond to Leg 86's Unit III described as interbedded soft sediment and chert. Chert was recovered from this zone in all Site 581 drill holes. Figure 7 shows the bathymetry for this region extremely northward to Hokkaido Trough which is located approximately $50 \mathrm{mi}$. to the north of Site 581. No specific trends, other than the Hokkaido Trough are evident in the bathymetry; however, the sampling may not be dense enough to do so.

\section{SEISMIC PROGRAM}

The major objective of the Leg 88 drilling program was to conduct seismic monitoring experiments using borehole and ocean-bottom sensors.

Specifically, the objectives of the program were (1) to compare background noise levels between seafloor and borehole seismometers, (2) to study the characteristics of long-range seismic propagation as recorded by the two types of instruments, (3) to study anisotropy in upper oceanic crust by particle motion analysis of three-component data, (4) to determine the seismic structure of the oceanic crust in the vicinity of Site 581 , and (5) to study regional seismicity and propagation of seismic energy from more distant natural seismic sources.

To carry out these objectives, a two-ship operation was planned using Glomar Challenger to emplace and record data from borehole sensors while the U.S.N.S. De Steiguer was used to deploy ocean bottom seismometers (OBS) and detonate explosive changes as artificial seismic sources. One of these, the Marine Seismic System (MSS), was developed under the direction of the Naval Ocean Research and Development Activity (NORDA) under funding from Defense Advanced Research Projects Agency (DARPA). The emplacement and testing of the instrument was the first priority of this experiment. The second borehole package, the ocean sub-bottom seismometer (OSS) was developed by the Hawaii Institute of Geophysics (HIG) with funding from the Office of Naval Research. The intent was to deploy the HIG instru-

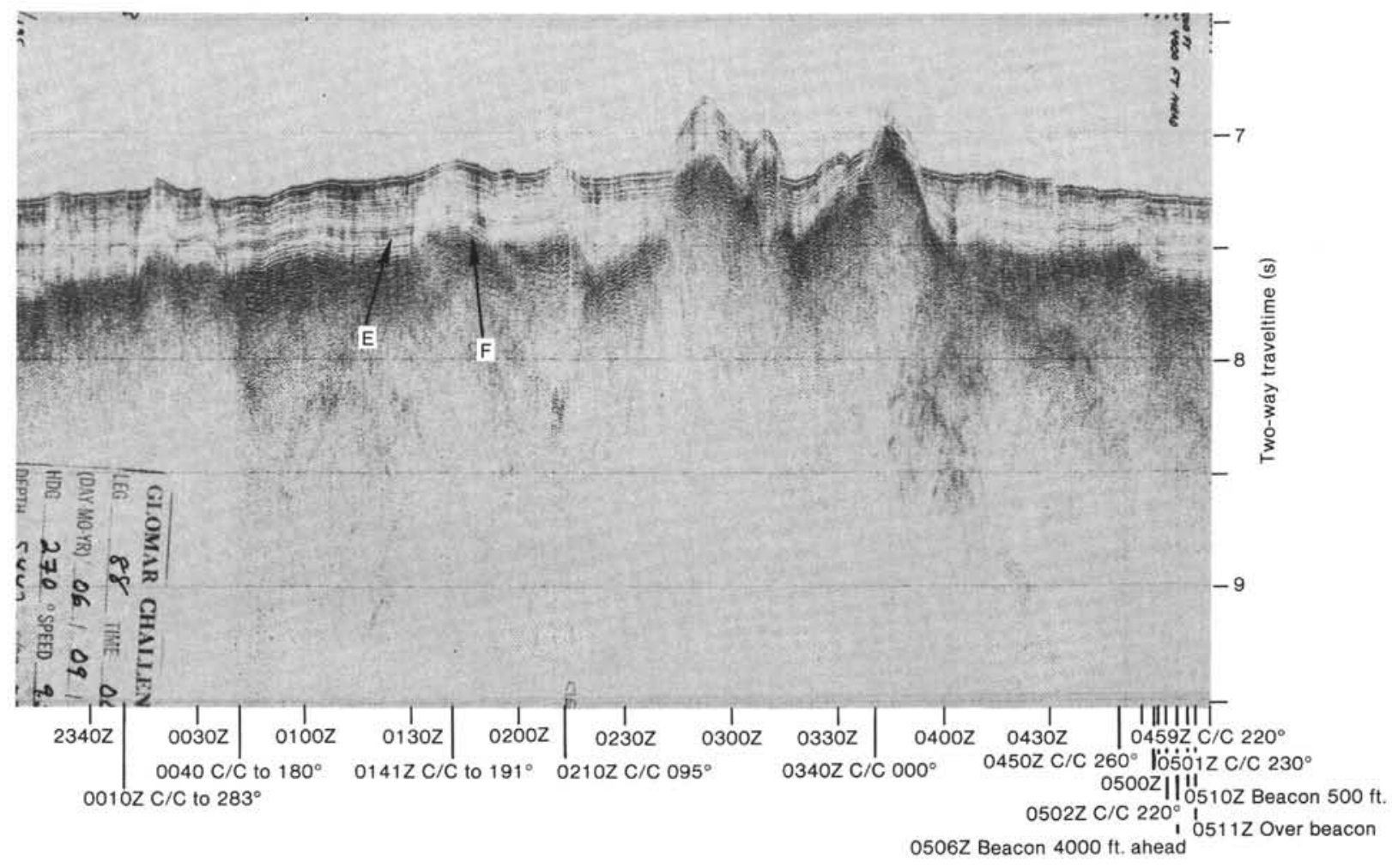

Figure 6. Normal-incidence reflection record, air-gun source from Glomar Challenger approaching Hole 581B. E is a highly reflective horizon, and $\mathrm{F}$ is acoustic basement. 


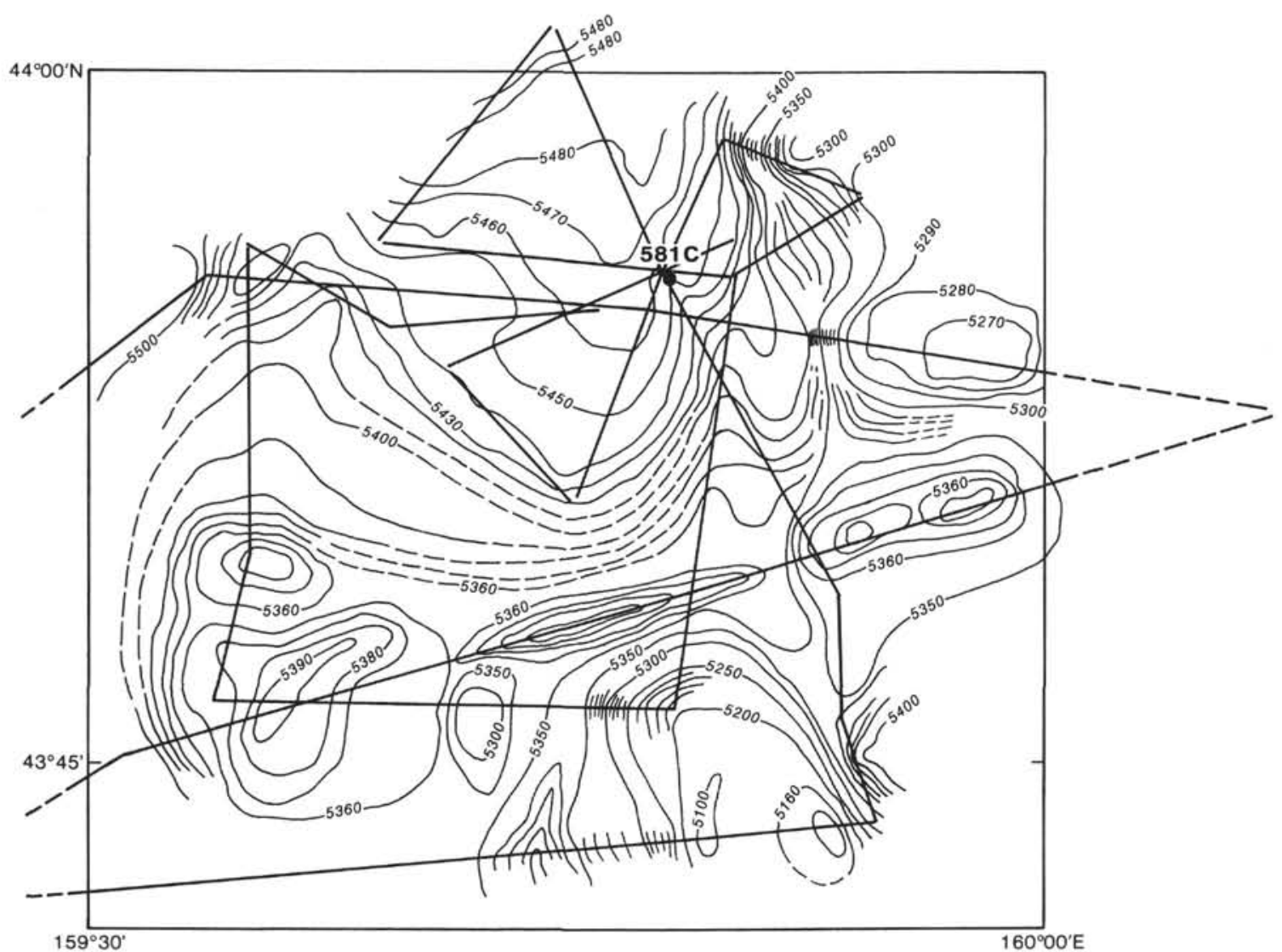

Figure 7. Contour chart of the region in the vicinity of Site 581, combining U.S.N.S. De Steiguer and Glomar Challenger bathymetric data. The contour interval is $10 \mathrm{~m}$. The location of Hole $581 \mathrm{C}$ is indicated.

ment in a second borehole close to the MSS site to allow comparison of the two instruments. OBSs from HIG and Oregon State University (OSU) were deployed at distances of 2 to $40 \mathrm{~km}$ from the boreholes.

The MSS consisted of a borehole package containing three-component seismic sensors. The sensor package is connected to a long EM cable, which can be connected to a surface ship recording system or to a seafloor processing and recording package. The data are transmitted along the cable in digital form. Recording in the surface ship may be carried out in digital form or data may be converted to analog form for recording and display. The seafloor recording package records continuous digital data for a period of up to 45 days at a sampling rate of up to $40 \mathrm{samples} / \mathrm{s}$. In order to emplace the borehole sensor package of the MSS, a hole with a reentry cone and casing is required.

Like the MSS, the OSS employs a borehole sensor package connected by a long EM cable to a surface ship or a seafloor recording ship. The sensor package contains a three-component $4.5-\mathrm{kHz}$ seismic sensor. The signal received by the seafloor recording package is converted to analog form and frequencies as high as $20 \mathrm{~Hz}$ are recorded. Recording can be carried out for a period of up to 75 days. The OSS is deployed through the drill string and therefore does not require a reentry hole.

Three different designs of ocean bottom seismometers were deployed during the experiment. All were free- vehicle instruments, which release from their seafloor anchors at a pre-assigned time. Some of the instruments also had acoustic recall capability. The HIG instruments recorded vertical, and one component of horizontal, ground motion using $4.5-\mathrm{Hz}$ geophones, deployed in a small external package away from the main recording package. These two signals along with a hydrophone output and a time base are recorded in analog form on magnetic tape. The OSU instruments are of two types. The sensor array is the same as the HIG instrument with the important difference being that the geophones are contained within the main recording package. Like the HIG instrument, recording is done in analog form. The second type of OSU instrument uses an external three-component, $4.5-\mathrm{Hz}$ geophone package and a hydrophone as sensors. It operates in an event-triggered or pre-assigned window mode, rather than a continuous mode, and records data digitally.

The explosives used as seismic sources were TOVEX and TNT. Shots ranging in size from 0.23 to $818 \mathrm{~kg}$ were used. The $818 \mathrm{-kg}$ shots were floated so they did not sink to too great a water depth during the time the ship was moving away from the charge.

The shooting program was intended to be carried out during the time that the OBSs were on the seafloor, after the MSS was emplaced in the borehole and during the time that MSS data was being recorded on board Glomar Challenger. A series of large $455-\mathrm{kg}$. shots were to 
be fired at distances as great as $500 \mathrm{~km}$ from the MSS in order to facilitate study of long-range seismic propagation. In addition, a series of smaller shots $(0.23$ to 116 $\mathrm{kg}$ ) was planned at closer range to the MSS.

Upon arrival of De Steiguer at the site of the experiment, five HIG OBSs, four OSU analog OBSs, and one OSU digital OBS were deployed. Locations of the instruments retrieving data are shown in Figure 8. One OSU instrument failed to record data because of a tape jam, and a second OSU instrument returned to the surface but was recovered with its recording package missing. Since two attempts at drilling a reentry hole for emplacement of the MSS failed, a third hole was drilled and the OSS was placed at a depth of $30 \mathrm{~m}$ below the sediment/basalt contact.

Because of the delays in carrying out Glomar Challenger operations in emplacing a borehole seismic instrument, the shooting program was carried out in two parts. The first part consisted of 252 shots first to the OBSs only. Initially, seven $818-\mathrm{kg}$. charges were fired at distances of 60 to $300 \mathrm{~km}$ south of Glomar Challenger. Weather conditions altered the original plan for shooting to distances out to $500 \mathrm{~km}$. A cross pattern of $120-\mathrm{km}$ lines was fired, with charges ranging in size from 8 to $64 \mathrm{lbs}$. and spaced at $1-\mathrm{km}$ intervals. Figure 9 shows the shot locations for all shots in this phase except for the more distant $818 \mathrm{-kg}$ shots.

The second shooting phase was carried out after the OSS was successfully emplaced. Shot lines crossed the borehole at various azimuths and a circular pattern of shots was carried out at a range of $10 \mathrm{~km}$ from the borehole. The first 44 shots of this phase were recorded by OSU OBSs prior to their recovery. Figure 10 shows the locations of shots fired during the phase.

Despite the problems that arose in carrying out the experiment, a great deal of high-quality seismic data were

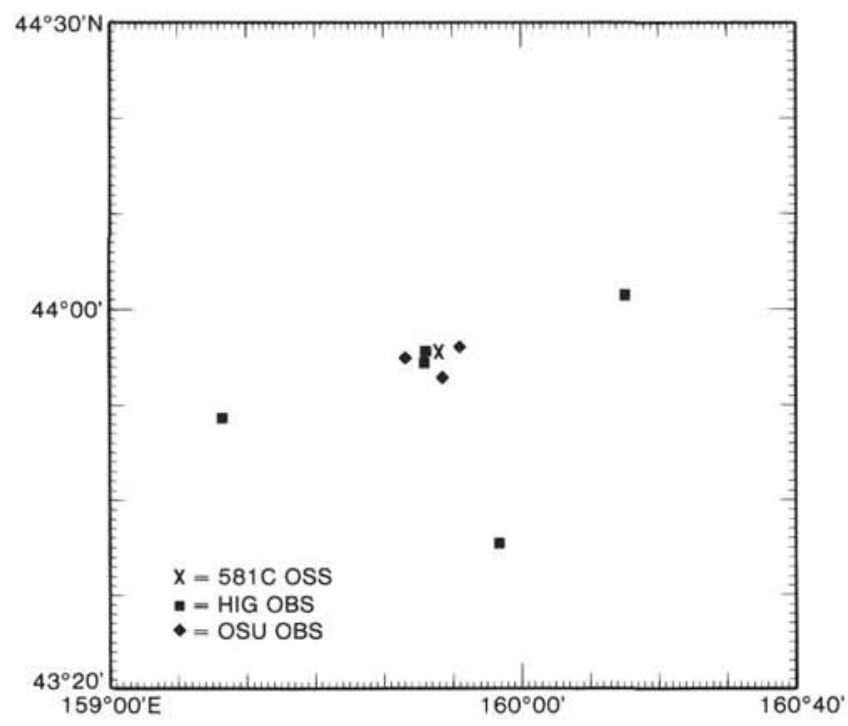

Figure 8. Locations of OSU and HIG ocean-bottom seismometers that successfully returned data during Leg 88 . collected. That, and subsequent analysis, allowed most of the project objectives to be addressed.

\section{SUMMARY AND CONCLUSIONS}

Site 581 lies just south of the Hokkaido Trough in the northwest Pacific Basin. The age of the crust at the site is slightly more than 110 m.y., based upon magnetic anomalies. Drilling results from Leg 86 indicate that the sediments are $345 \mathrm{~m}$ thick, and the lower $75 \mathrm{~m}$ is composed of cherty layers.

More than $20 \%$ of the world's seismic energy is released in the Aleutian-Kurile seismic zone, where the Pacific Plate is actively being subducted. Site 581 is within this highly active seismic zone. The primary objective of this leg was to deploy two permanent borehole seismometers within the ocean crust at Site 581, in order to study earthquakes generated in subduction zones and the seismic structure of the old Pacific Plate crust and lithosphere.

A wide-band, wide dynamic range seismic system in a low ambient noise marine environment, such as Site 581 , will provide information contributing to many scientific objectives including:

1. Information on earthquake occurrence rates;

2. Determining the magnitude of changes of seismic properties of the oceanic crust with age;

3. Determining plate structure by seismic refraction;

4. Measuring signal absorption and propagation characteristics for both long- and short-period body and surface waves;

5. Evaluating source mechanisms within regional distances of an actively subducting plate boundary;

6. Measuring crustal and upper mantle anisotropy;

7. Determining relationships between seismic background noise beneath the seafloor and environmental parameters;

8. Measuring elastic and rheological properties of converging plates; and

9. Making long-term measurements of borehole temperature.

Instruments utilized for the planned deployments were the Marine Seismic System (MSS), developed by the Defense Advanced Research Projects Agency (DARPA), and the Ocean Sub-bottom Seismometer (OSS), developed by the Hawaii Institute of Geophysics (HIG). The DARPA system consists of four Teledyne S-750 seismometers (two vertical and two orthogonal horizontal components $2-20 \mathrm{~Hz}$ ), two triaxial accelerometers, a pressure sensor, and four temperature sensors. The HIG system is similar to the MSS in function, but simpler in design. It transmits eight channels of digital data (three seismic, two tilt, one temperature, hole diameter, and engineering) up the cable for recording.

Unfortunately, only the HIG instrument was successfully deployed. Deployment of the DARPA system could not be attempted as drilling equipment failure, downhole conditions, and foul weather prevented the completion of the reentry hole required for the MSS emplacement. The OSS required only a single-bit hole and was 


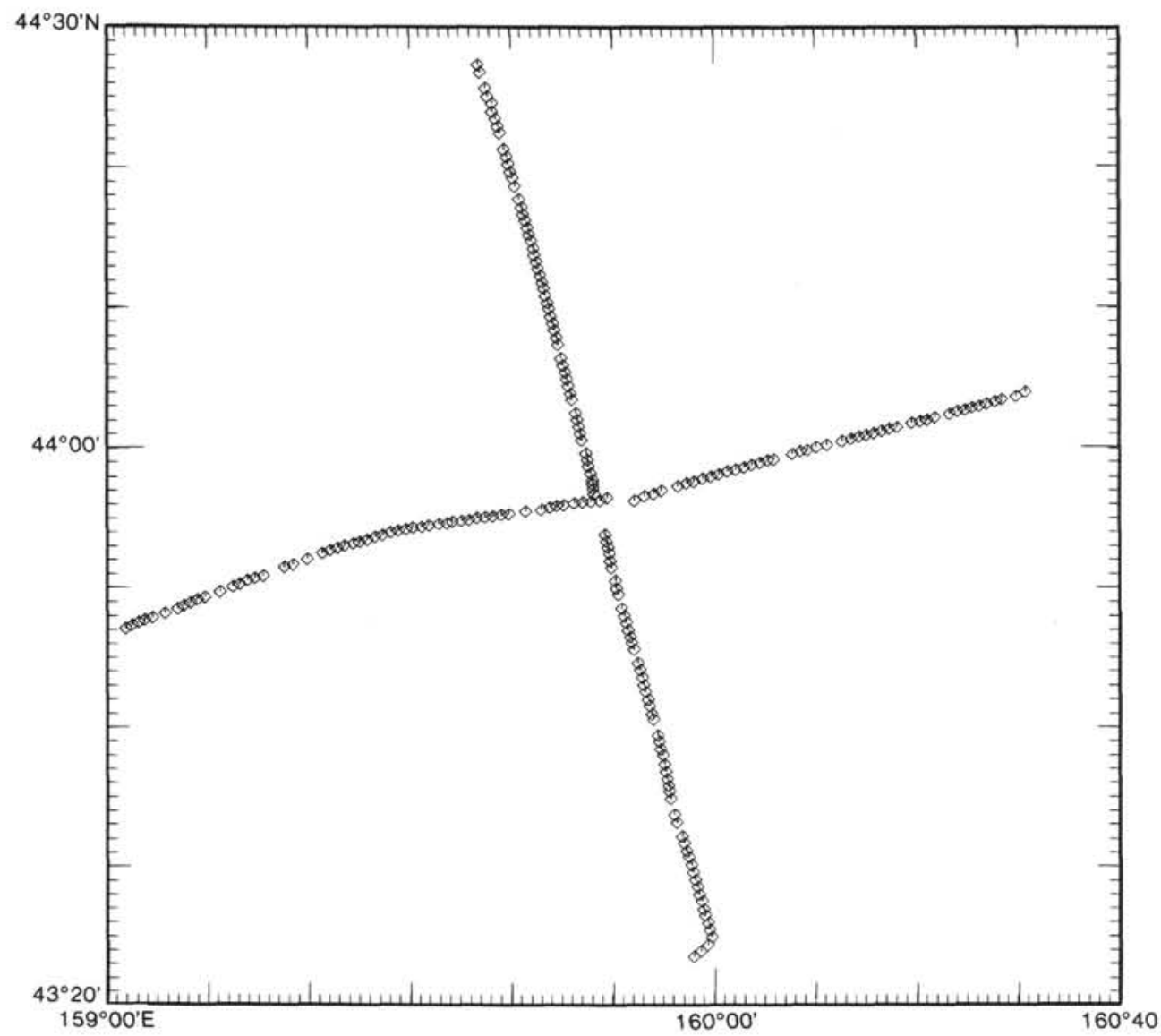

Figure 9. Locations of explosive shots fired by U.S.N.S. De Steiguer during the first phase of the Leg 88 shooting program. These shots were recorded only by seafloor seismometers. Locations of $1800-\mathrm{lb}$. shots fired at distances of 60 to $300 \mathrm{~km}$ are not shown.

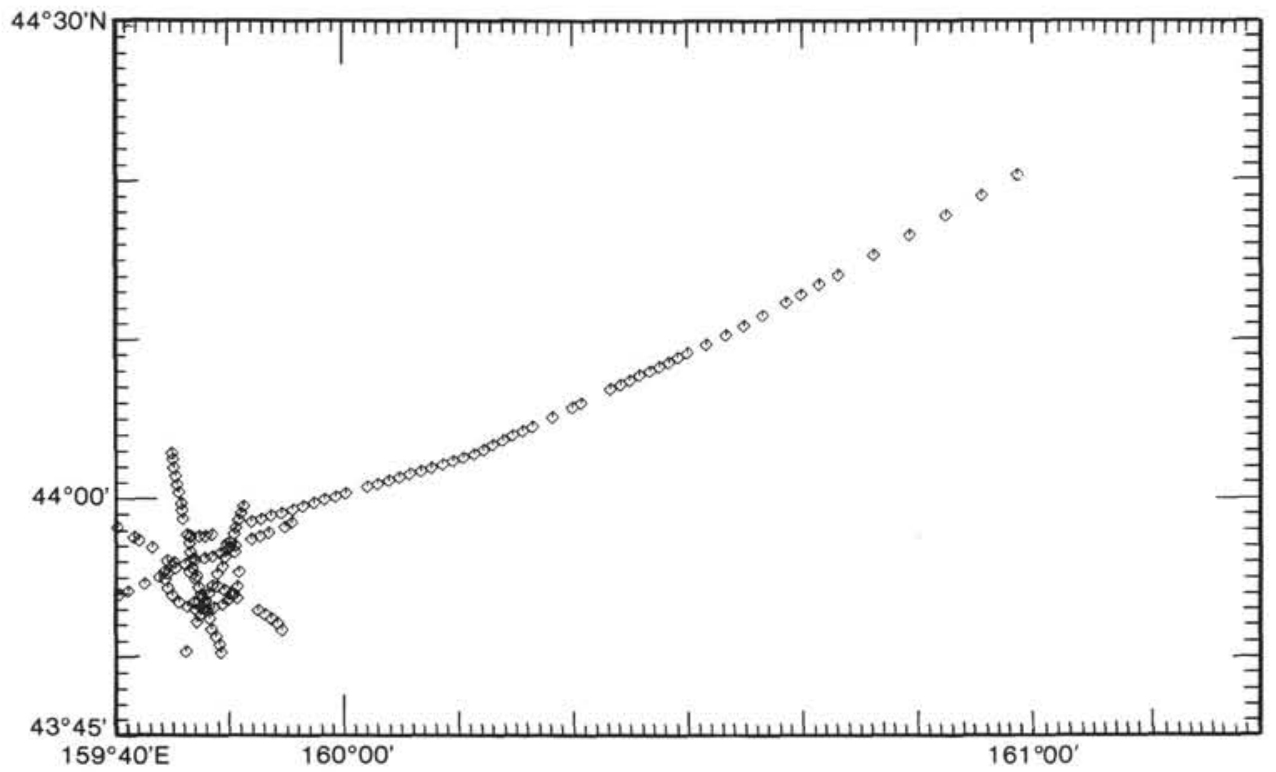

Figure 10. Locations of explosive shots fired by U.S.N.S. De Steiguer during the second phase of shooting. All of these shots were fired during the time that the OSS was in operation with data being recorded on board Glomar Challenger. 
deployed at Hole $581 \mathrm{C}$ in $5867 \mathrm{~m}$ of water. The seismometer is coupled to oceanic basalt near the bottom of the 380-m-deep hole. One hundred eighty-five shots were fired to the OSS by the accompanying vessel De Steiguer and recorded by the OSS with printout aboard Glomar Challenger. The instrument was left in the hole and the recorder package lowered to the seafloor. Continuous recording of data occured until 15 November 1982.

A first test was made of the prototype wireline reentry system, designed and constructed by the Deep Sea Drilling Project at Scripps Institution of Oceanography. Unfortunately, equipment failure precluded a complete and comprehensive test of the device, so the results are inconclusive.

\section{REFERENCES}

Aubouin, J., von Huene, R., et al.,'1982. Init. Repts. DSDP, 67: Washington (U.S. Govt. Printing Office)

Fountain, J. C., Jacobi, R. D., and Fahey, T. J., 1985. Petrology and geochemistry of basalts from Deep Sea Drilling Project Leg 86, Site 581. In Heath, G. R., Burckle, L. H., et al., Init. Repts. DSDP, 86: Washington (U.S. Govt. Printing Office)

Heath, G. R., Burckle, L. H., et al., 1985. Init. Repts. DSDP, 86: Washington (U.S. Govt. Printing Office).

Lewis, B. T. R., Robinson, P., et al., 1983. Init. Repts. DSDP, 65; Washington (U.S. Govt. Printing Office).

Salisbury, M., Hyndman, R., et al., 1984. Init. Repts. DSDP, 78B: Washington (U.S. Govt. Printing Office). 

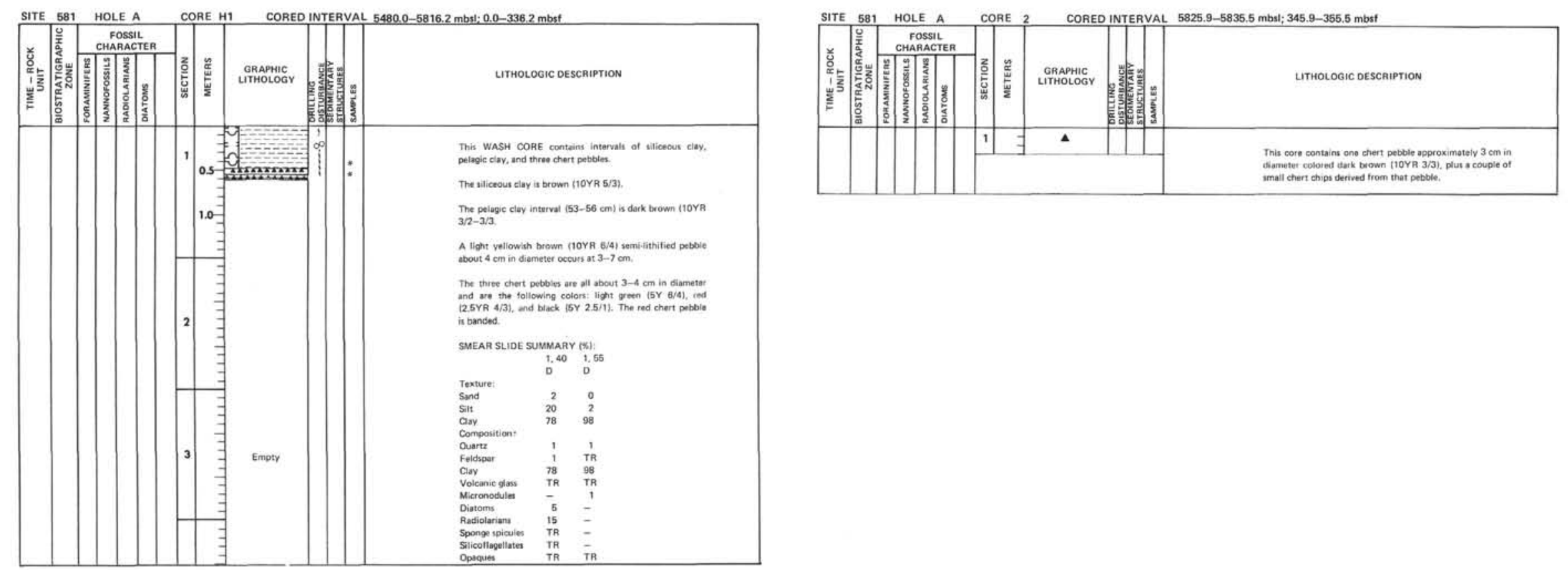


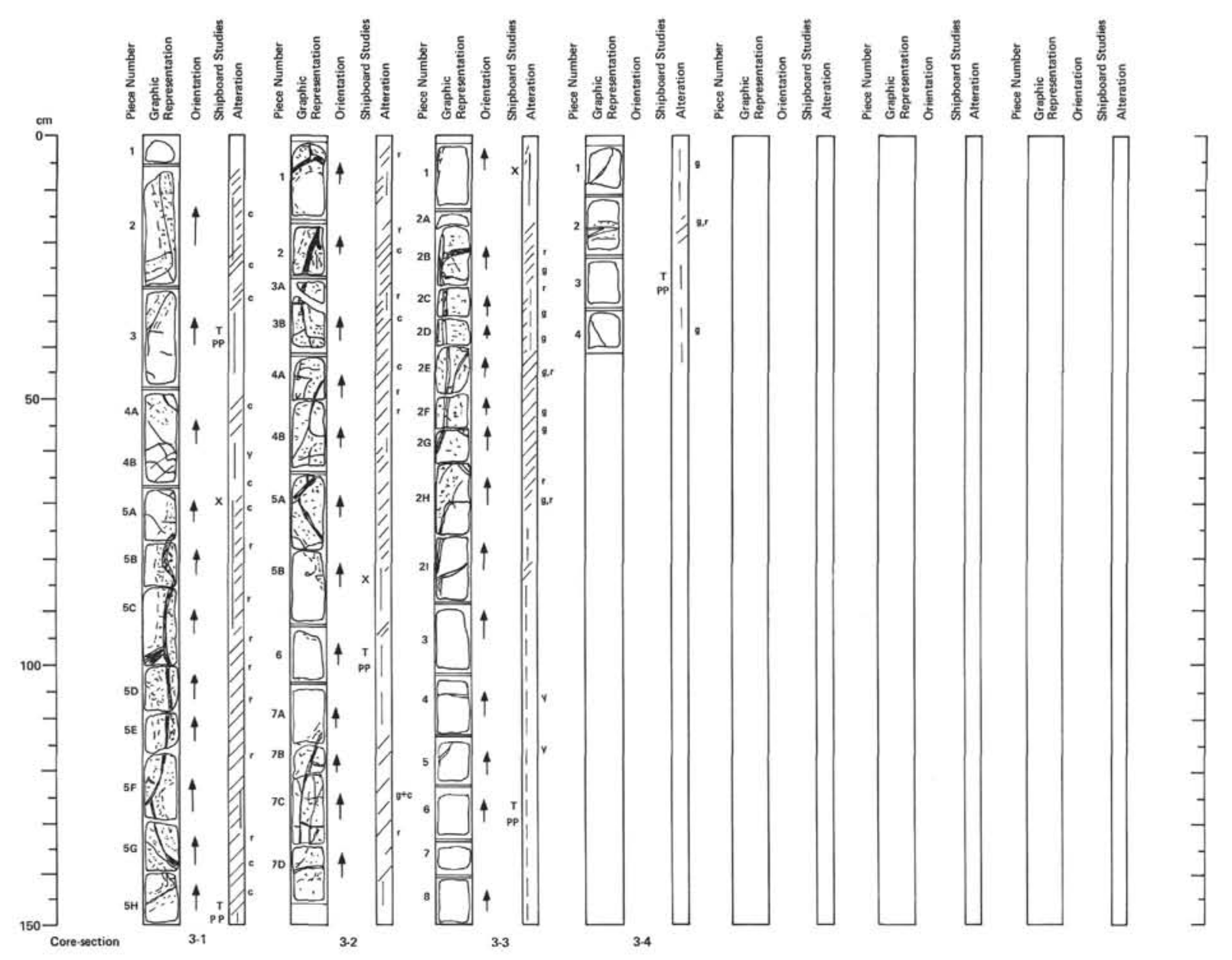

8514.3

Depth 355.5-300.4 mbat 


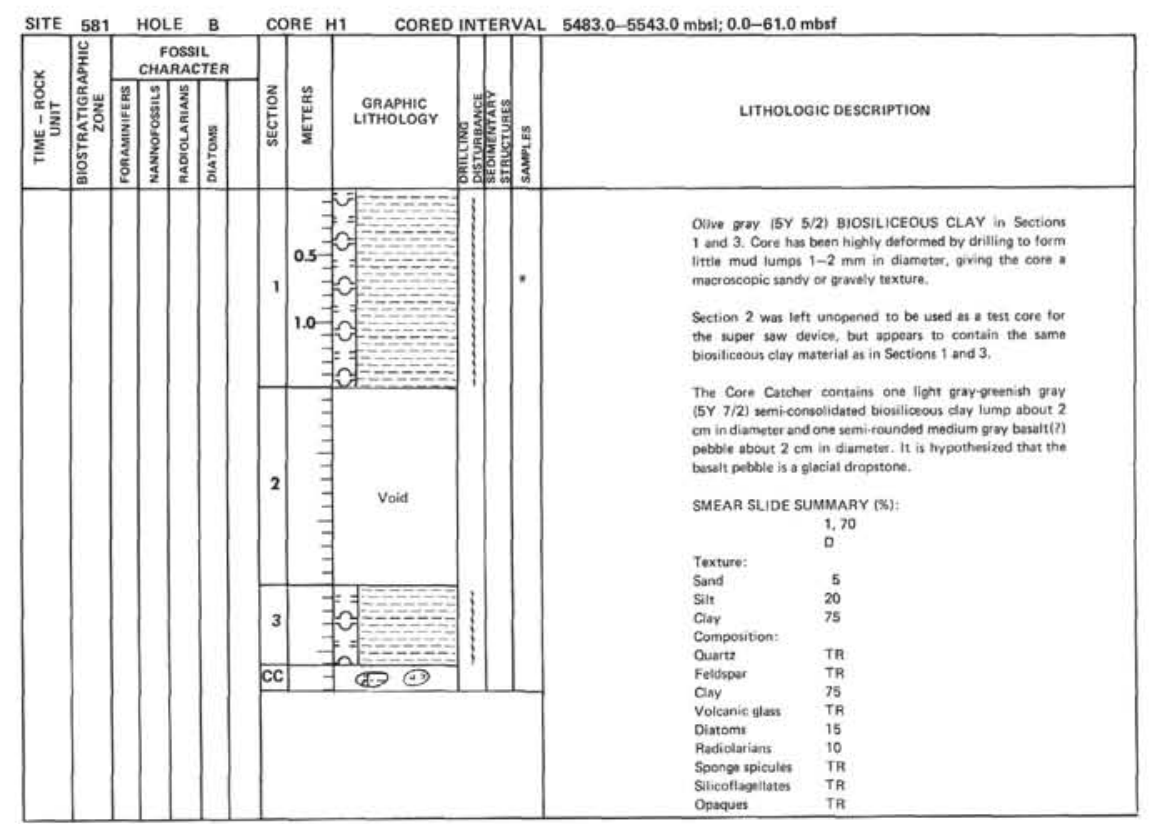

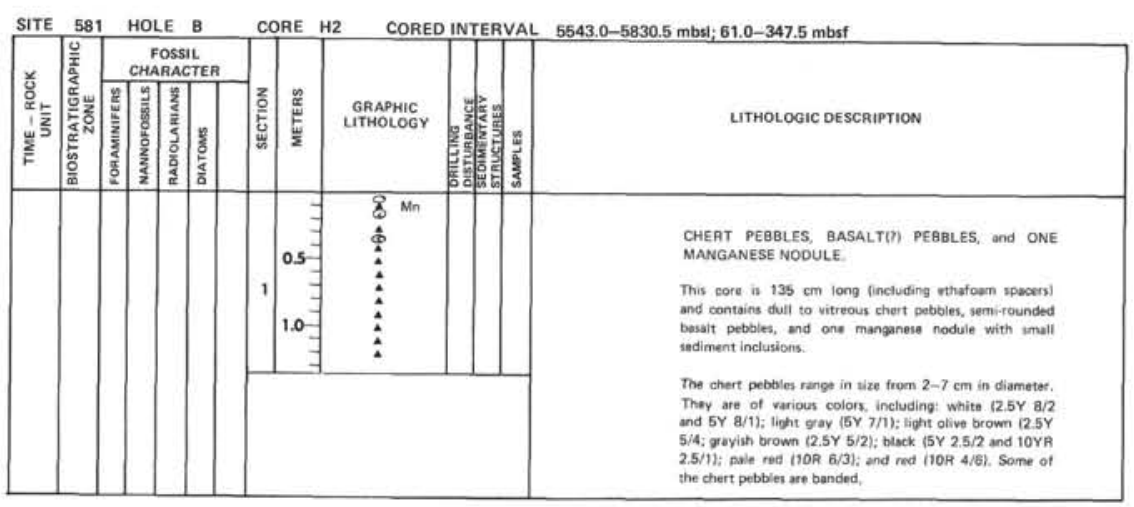




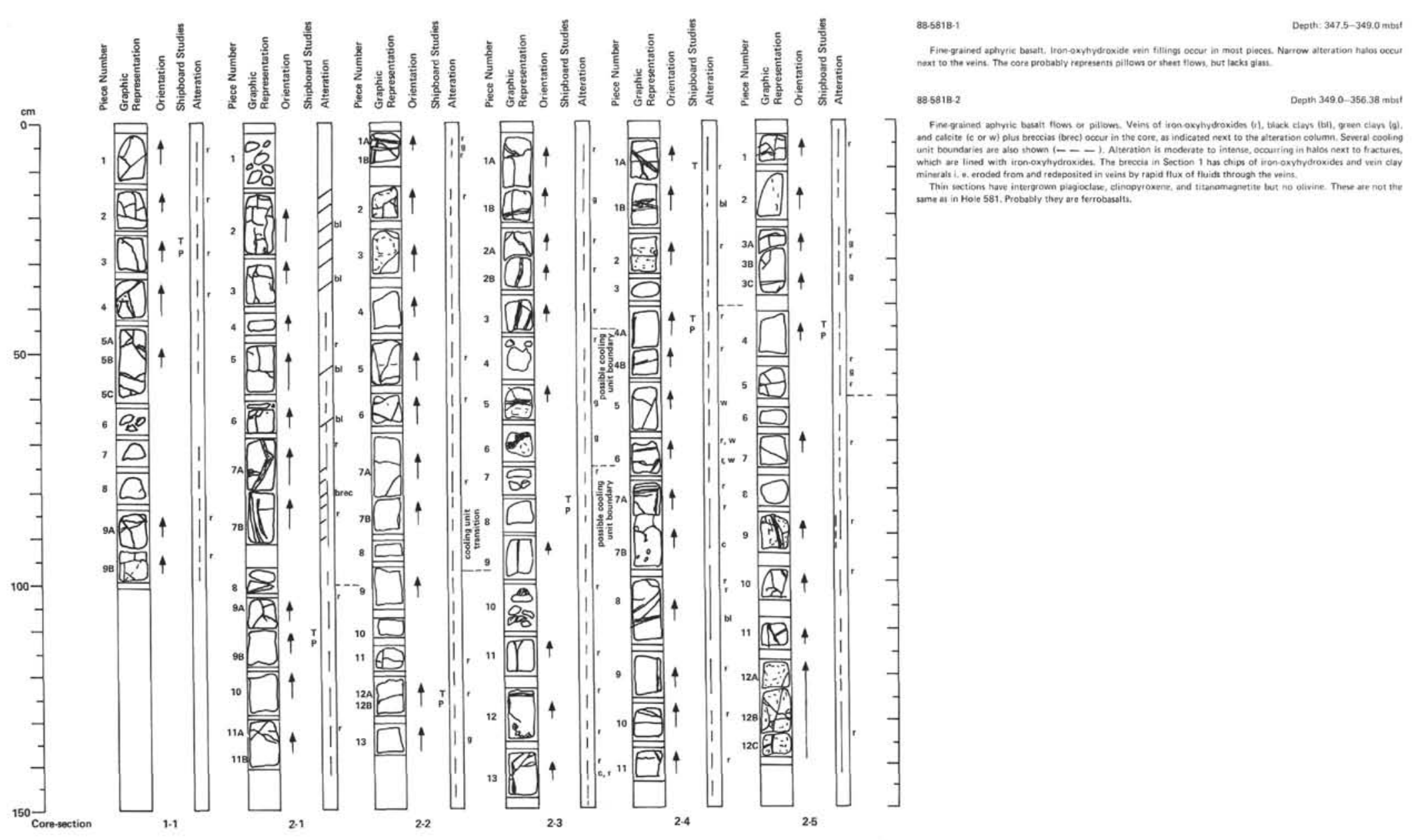




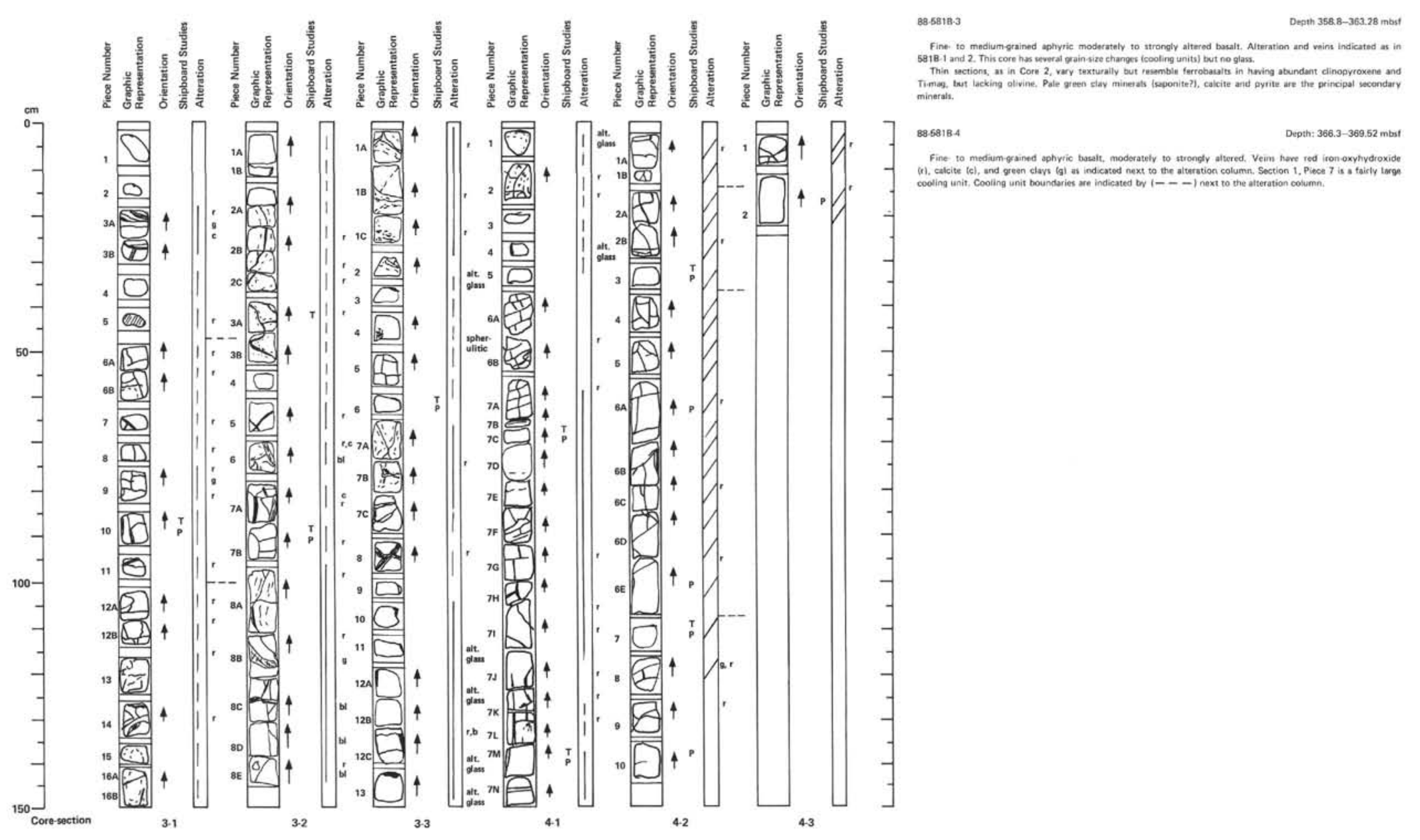


SITE 581 HOLE C COAE H1 CORED INTERVAL $5569.1-5839.6$ mbs; 87.1-367.6 mbst

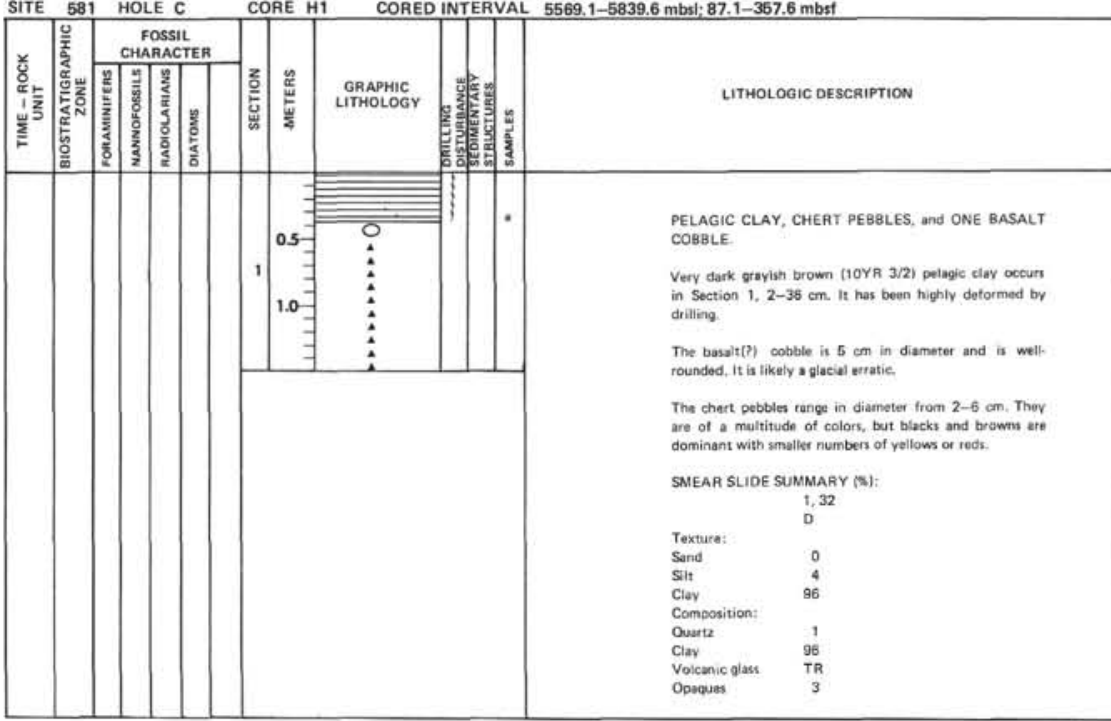




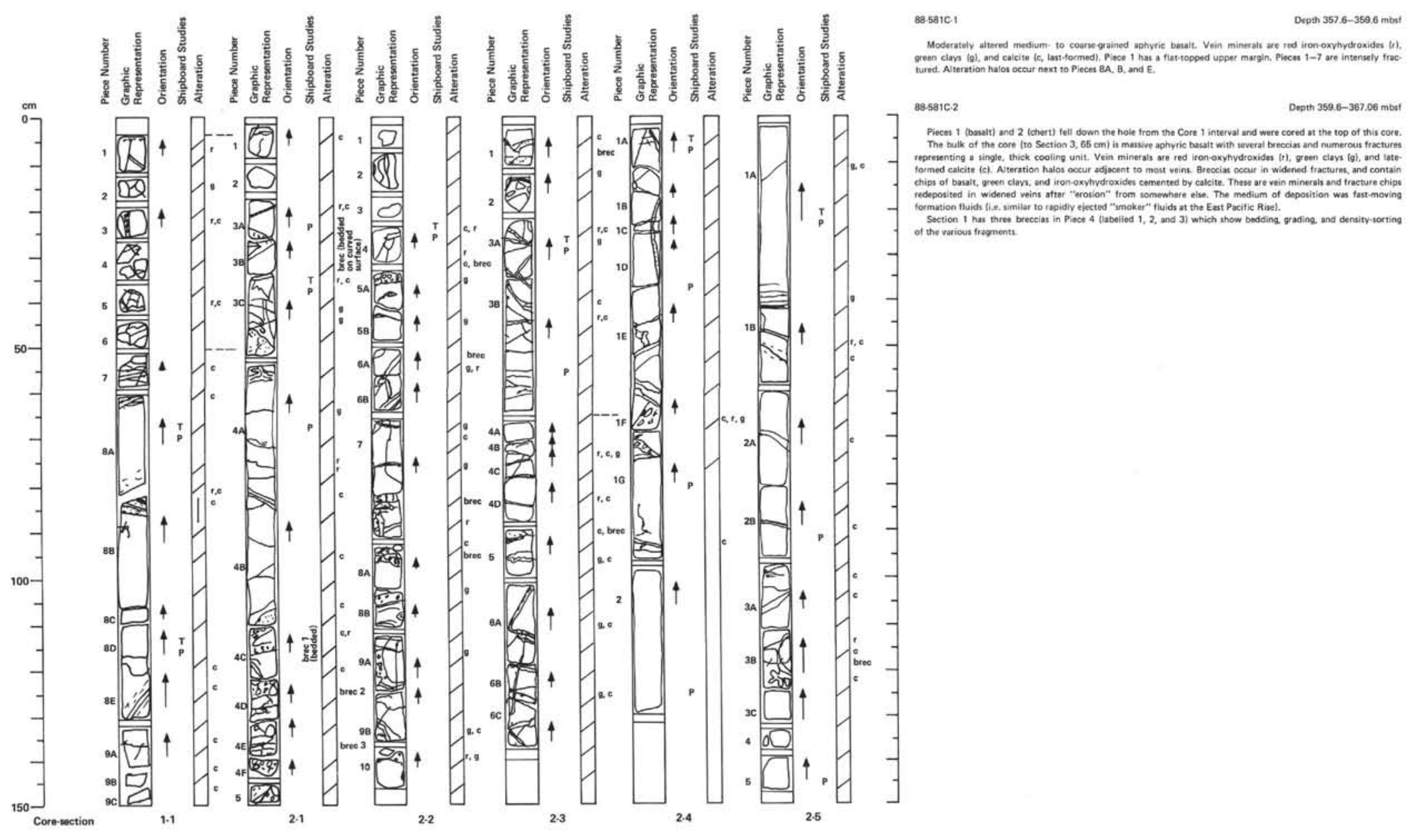




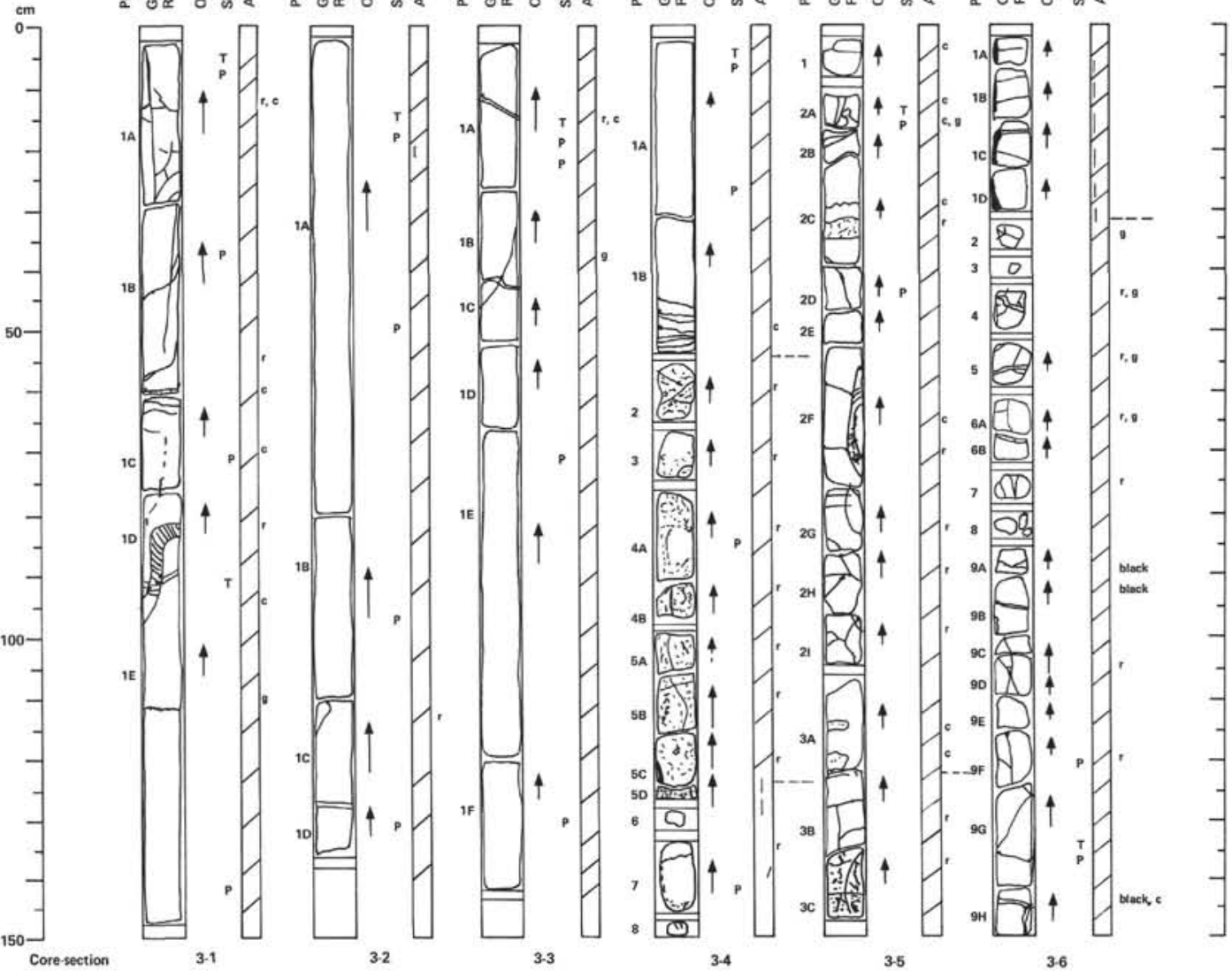




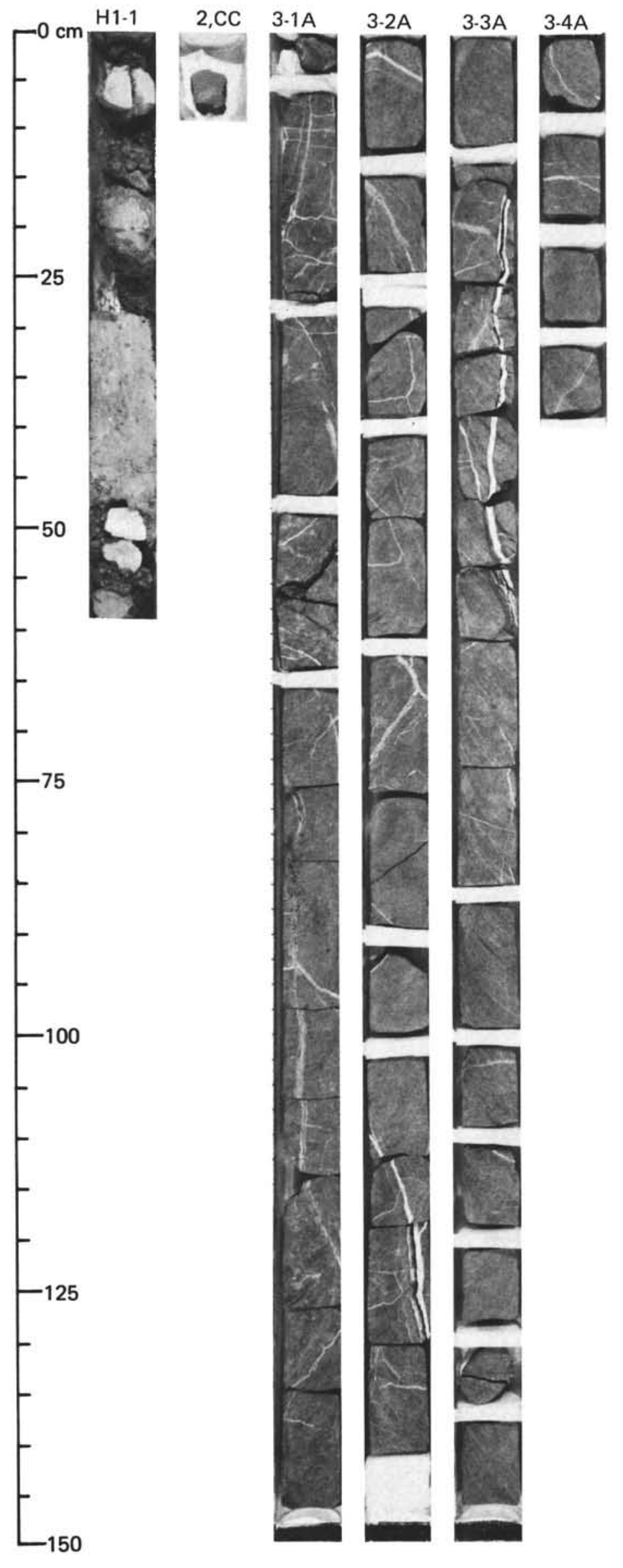


SITE 581 (HOLE 581B)

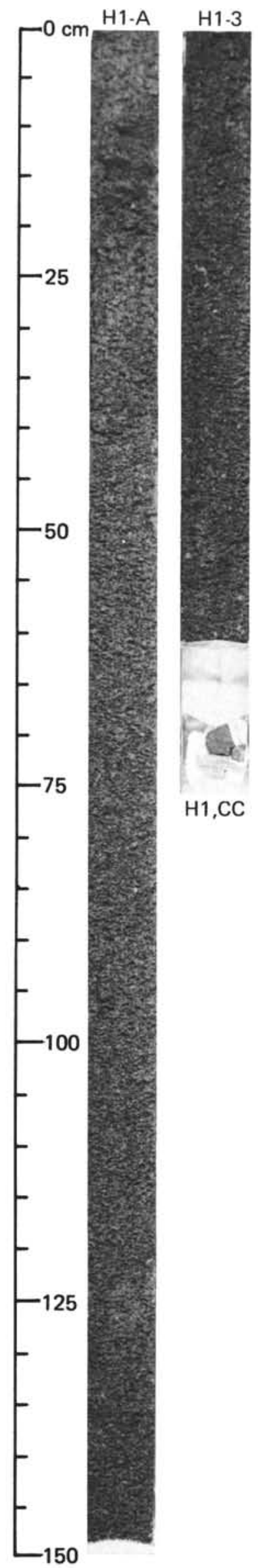




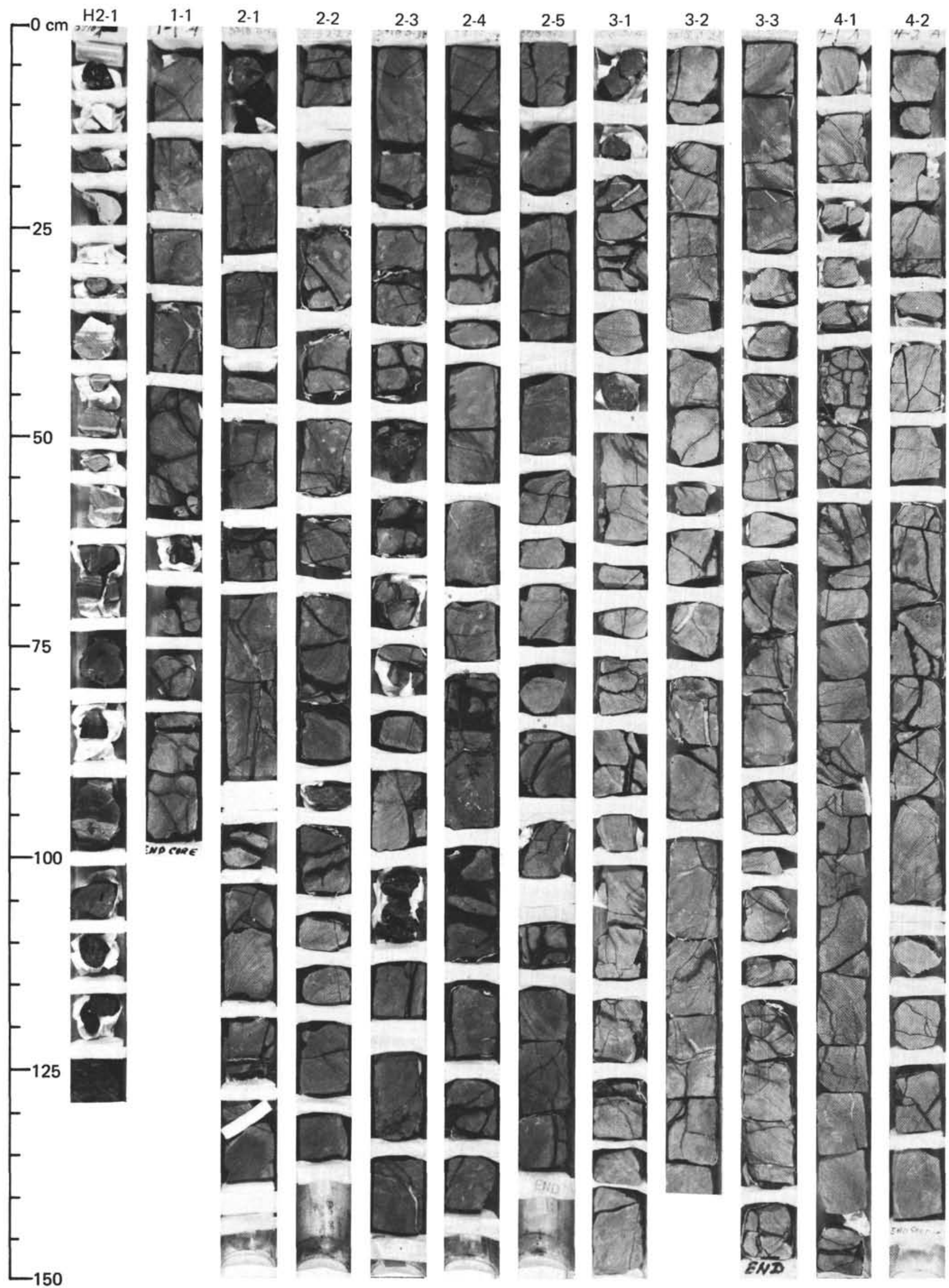


SITE 581 (HOLE 581B)

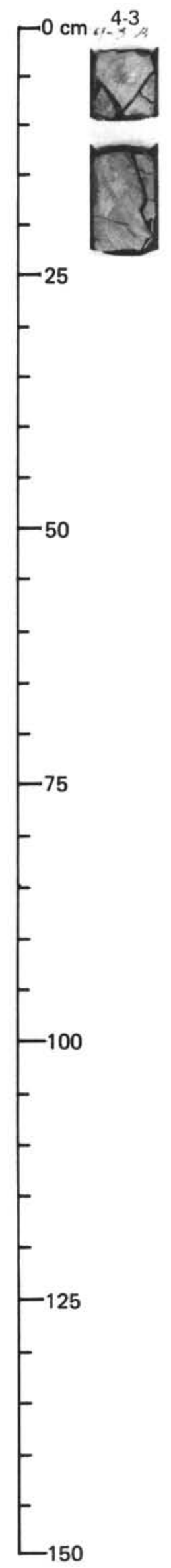

34 
SITE 581 (HOLE 581C)

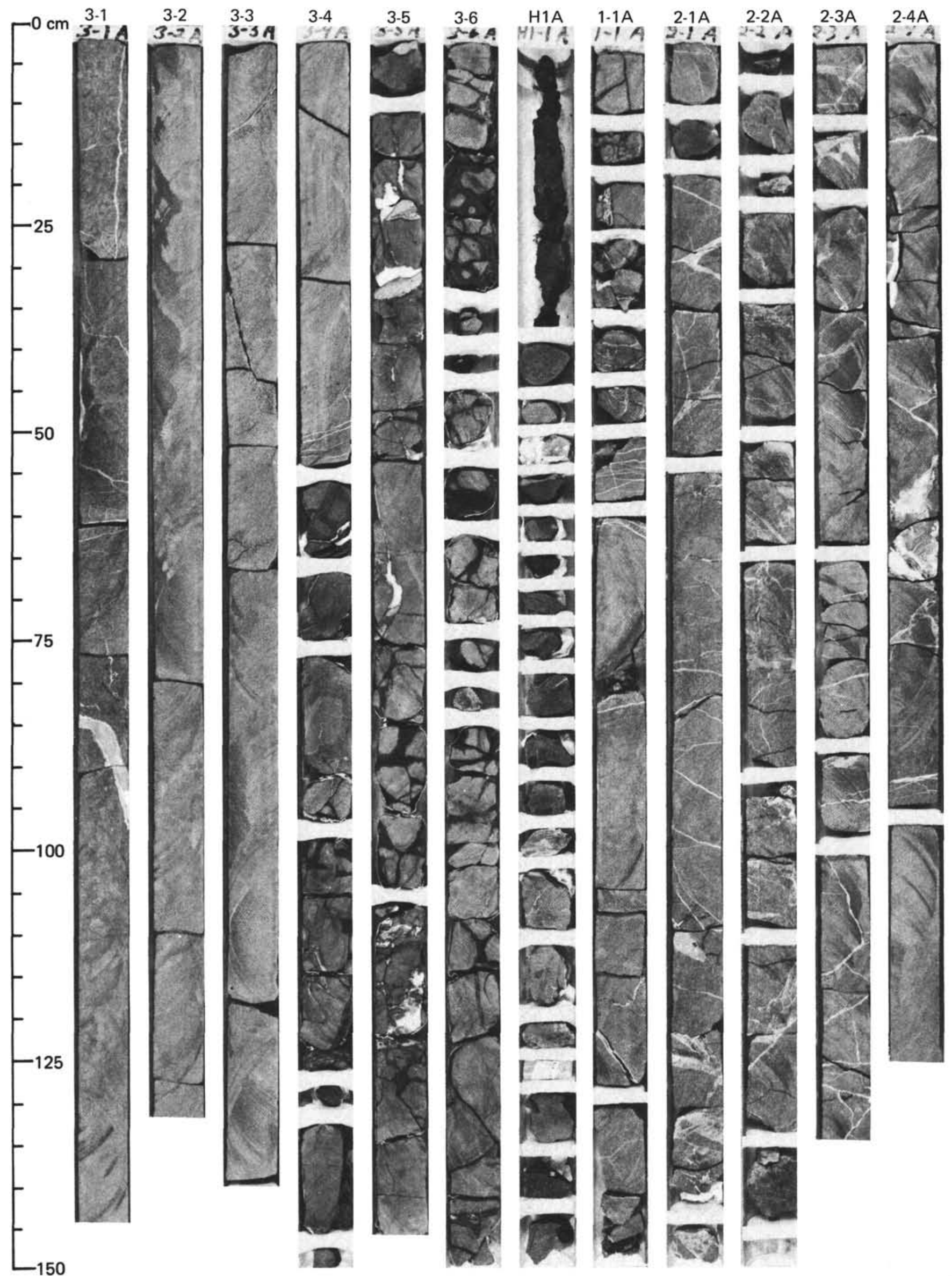


SITE 581 (HOLE 581C)

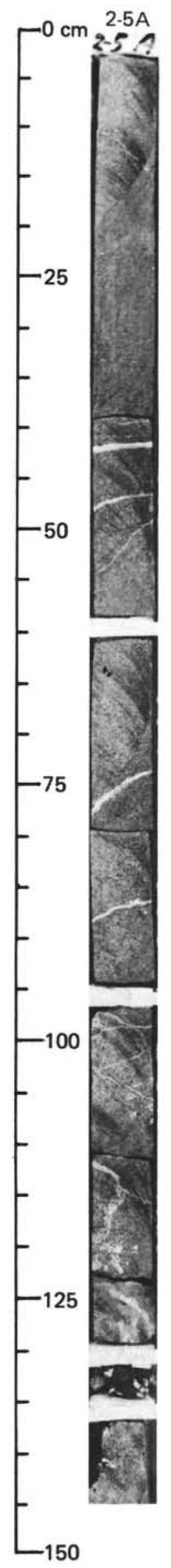

